\title{
Biopolymer and Biomaterial Conjugated Iron Oxide Nanomaterials as Prostate Cancer Theranostic Agents: A Comprehensive Review
}

\author{
Md. Abu Rayhan ${ }^{1} \mathbb{D}$, Md. Sakib Hossen ${ }^{2} \mathbb{D}$, Mahruba Sultana Niloy ${ }^{1}$, Mozammel Haque Bhuiyan ${ }^{3} \mathbb{D}$, \\ Sudip Paul ${ }^{1,4,5, *}$ and Md. Salman Shakil ${ }^{6, *(\mathbb{D})}$ \\ 1 Department of Biochemistry and Molecular Biology, Jahangirnagar University, Savar, \\ Dhaka 1342, Bangladesh; rayhanbmb.ju42@gmail.com (M.A.R.); mahruba.niloy@gmail.com (M.S.N.) \\ 2 Department of Biochemistry, Primeasia University, Banani, Dhaka 1342, Bangladesh; \\ sakib.hossen@primeasia.edu.bd \\ 3 Center for Bioengineering and Nanomedicine, Faculty of Dentistry, University of Otago, 362 Leith St, \\ North Dunedin, Dunedin 9016, New Zealand; mozammel.bhuiyan@postgrad.otago.ac.nz \\ 4 Metabolomics Laboratory, Baker Heart and Diabetes Institute, Melbourne, VIC 3004, Australia \\ 5 Department of Cardiometabolic Health, The University of Melbourne, Melbourne, VIC 3010, Australia \\ 6 Department of Pharmacology and Toxicology, University of Otago, 362 Leith St, North Dunedin, \\ Dunedin 9016, New Zealand \\ * Correspondence: sudip.paul@baker.edu.au (S.P.); salman.shakil@postgrad.otago.ac.nz (M.S.S.)
}

\section{check for} updates

Citation: Rayhan, M.A.; Hossen, M.S.; Niloy, M.S.; Bhuiyan, M.H.; Paul, S.; Shakil, M.S. Biopolymer and Biomaterial Conjugated Iron Oxide Nanomaterials as Prostate Cancer Theranostic Agents: A Comprehensive Review. Symmetry 2021, 13, 974. https://doi.org/ 10.3390/sym13060974

Academic Editor:

Stéphane Bellemin-Laponnaz

Received: 8 April 2021

Accepted: 18 May 2021

Published: 31 May 2021

Publisher's Note: MDPI stays neutral with regard to jurisdictional claims in published maps and institutional affiliations.

Copyright: (c) 2021 by the authors. Licensee MDPI, Basel, Switzerland. This article is an open access article distributed under the terms and conditions of the Creative Commons Attribution (CC BY) license (https:/ / creativecommons.org/licenses/by/ $4.0 /)$.

\begin{abstract}
Prostate cancer (PCa) is the most common malignancy in men and the leading cause of death for men all over the world. Early diagnosis is the key to start treatment at an early stage of PCa and to reduce the death toll. Generally, PCa expresses characteristic morphologic features and serum biomarkers; however, early diagnosis is challenging due to its heterogeneity and long-term indolent phase in the early stage. Following positive diagnosis, PCa patients receive conventional treatments including surgery, radiation therapy, androgen deprivation therapy, focal therapy, and chemotherapy to enhance survival time and alleviate PCa-related complications. However, these treatment strategies have both short and long-term side effects, notably impotence, urinary incontinence, erectile dysfunctions, and recurrence of cancer. These limitations warrant the quest for novel PCa theranostic agents with robust diagnostic and therapeutic potentials to lessen the burden of PCa-related suffering. Iron oxide nanoparticles (IONPs) have recently drawn attention for their symmetrical usage in the diagnosis and treatment of several cancer types. Here, we performed a systematic search in four popular online databases (PubMed, Google Scholar, Scopus, and Web of Science) for the articles regarding PCa and IONPs. Published literature confirmed that the surface modification of IONPs with biopolymers and diagnostic biomarkers improved the early diagnosis of PCa, even in the metastatic stage with reliable accuracy and sensitivity. Furthermore, fine-tuning of IONPs with biopolymers, nucleic acids, anticancer drugs, and bioactive compounds can improve the therapeutic efficacy of these anticancer agents against PCa. This review covers the symmetrical use of IONPs in the diagnosis and treatment of PCa, investigates their biocompatibility, and examines their potential as PCa theranostic agents.
\end{abstract}

Keywords: prostate cancer; iron oxide nanoparticles; early diagnosis; treatment; theranostics; biocompatibility

\section{Introduction}

Cancer symmetry theories are pertinent to loss of homeostasis in cancer and to its origin, spread, treatment, and resistance. Symmetry as well as symmetry breaking could offer a novel approach to deal with the cancer problem. Prostate cancer (PCa) is the second most commonly diagnosed and the leading cause of death in men all over the world [1,2]. According to the American Chemical Society, over 0.6 million men died of PCa while 
approximately 1.8 million men were diagnosed in 2020 [3]. It is predicted that the number of new cases and deaths associated with PCa will be approximately 2.3 and 0.74 million globally, respectively by 2040 [4]. To combat this deadly disease, early diagnosis and potent therapeutic agents are urgently needed to enhance the survival of PCa patients [5,6].

Early diagnosis is the key to assure PCa specific treatment [6]. However, being highly heterogenic and asymptomatic, PCa is hardly diagnosed at an early stage [7,8]. Conventional methods such as transrectal ultrasonographically guided biopsies, multiparametricmagnetic resonance imaging (mp-MRI), digital rectal inspection (DRE), and marker-based detection methods are routinely used in the clinical diagnosis of PCa [9-11]. However, these common methods are unable to detect PCa in the early stages and have other limitations. For instance, the common limitations of biopsy are missed cancer diagnosis, substantialgrade misclassification, upgrading, and downgrading of cancer. As a result, overtreatment of low-grade PCa and inadequate treatment of upgraded PCa increases the rate of death in patients [10]. Among the conventional methods of diagnosis, a biopsy is an invasive process and may also cause subsequent infection, erectile dysfunction, and urinary incontinence [12]. Additionally, mp-MRI using gadolinium (Gd) could detect transition zone and peripheral lesions of PCa [11]. However, Gd was found to be nephrotoxic and could not be used in liver-transplanted patients [13]. Furthermore, DRE is frequently used for the diagnosis of PCa; however, this method frequently provides false positive results [14]. Therefore, DRE is not reliable in routine screening of PCa [15]. Marker-based detection (e.g., PSA) of PCa screening was always under great debate due to lack of accuracy (i.e., specificity around 33\% and sensitivity around 86\%), identification of clinically insignificant diseases, and false diagnosis in the indolent phase [16]. After diagnosis, surgery (radical prostatectomy), radiation therapy (external beam radiation therapy, interstitial radiation implants also known as brachytherapy), cryoablation, androgen deprivation therapy (ADT), focal therapy, and chemotherapy have been frequently used to treat PCa for a long time [17]. However, these conventional treatment procedures often result in some short and long-term complications including impotence, urinary incontinence, erectile dysfunctions, bowel urgency, gynecomastia, osteoporosis, metabolic syndrome, depression, recurrence of cancer, lowering the longevity of life etc. [18-21]. Therefore, it is really necessary to advance specific methods for early detection and treatment.

The frontiers of cancer research are currently focusing on developing methods for early detection of PCa and on finding strategies that have fewer or no side effects [22]. Iron oxide nanoparticles (IONPs) have magnetic properties and belong to the ferromagnetic family. IONPs have drawn attention to diagnosis, prognosis, and treatment of PCa due to special properties such as stability, dispersibility in desired solvents, biocompatibility, large surface-to-volume ratio, and more [23,24]. Upon surface modifications, a multifunctional IONP with symmetrical functions both as a chemotherapeutic (hyperthermic) and a $\mathrm{T}_{2}$ MRI contrast agent with enhanced imaging capacity can be developed [25]. For being target-specific, multifunctional nanoplatforms deliver drugs specifically to the malignant cells rather than affecting normal cells and reduce the side effects [22,25]. Therefore, the disease diagnosis and therapeutic potential of IONPs make them suitable theranostic agents against $\mathrm{PCa}$ [26-28].

In this review, we have summarized the PCa theranostic potential of different types of IONPs in conjugation with other polymers, antibodies, nucleic acids, and ligands/receptors along with their mechanism of actions, pitfalls, challenges, and biocompatibility.

\section{Materials and Methods}

This systematic review was performed to assess the role of synthesized IONPs as PCa theranostics. We considered published original research articles in different international journals on PCa diagnosis and treatment by IONPs. 


\subsection{Search Strategy}

Online international databases including Google Scholar, PubMed, Scopus, and Web of Science were used to collect the relevant and specific articles systematically. The systematic search was performed on 21 December 2020 irrespective of publication date. The keywords for search comprised "iron oxide", and "prostate cancer". The flow chart shows the search strategy of articles for primary studies (Figure 1).

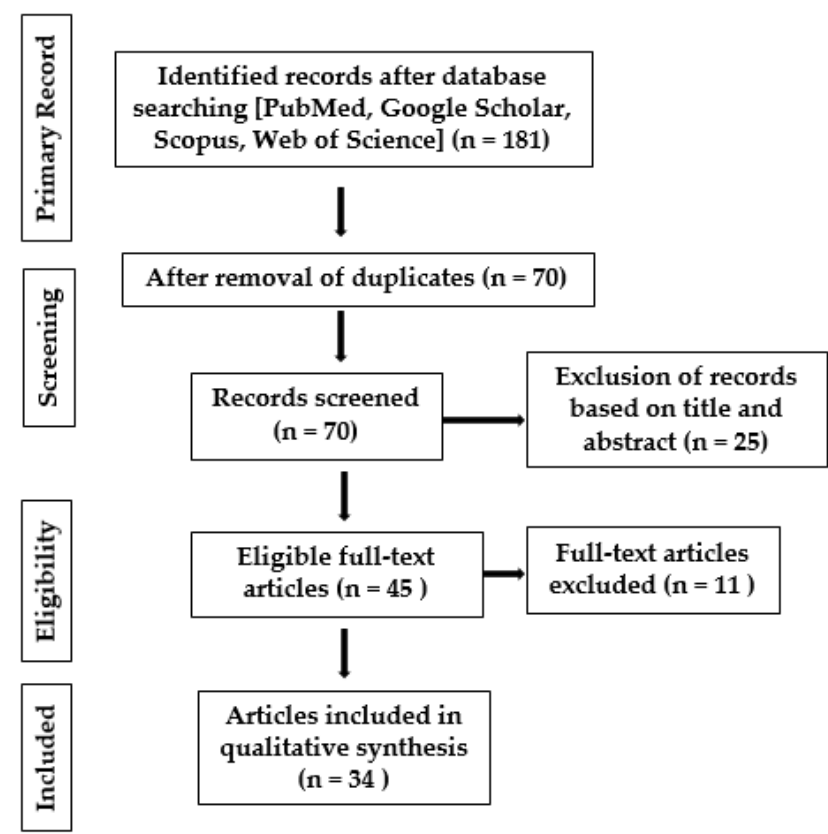

Figure 1. PRISMA flow diagram of study design. Articles were searched with the keywords "iron oxide", and "prostate cancer" from PubMed, Google Scholar, Web of Science, and Scopus; 34 articles were included finally.

\subsection{Study Selection}

We screened the article title, abstract, and full texts to evaluate their eligibility for the present study. To avoid any bias or error, two authors searched, reviewed, and selected the manuscripts independently.

\subsection{Inclusion Criteria}

We considered original research papers, papers written in the English language, published, and/or in press papers, papers that reported PCa diagnosis and treatment using IONPs.

\subsection{Exclusion Criteria}

Duplicated research papers, original research papers written in languages other than English, review articles, papers with abstract only, and letters that showed the application of IONPs in diagnosis or treatment of PCa were excluded in the present study.

\section{Prostate Cancer}

PCa is a heterogeneous malignant disease that arises from several molecular modifications leading to variable clinical complications [29]. Common molecular alterations that have been observed in PCa are hypermethylation, loss of heterozygosity, inactivation of tumor suppressor genes, and gene mutations [30]. PCa can be classified into 5 main types: (i) glandular neoplasm (ii) urothelial carcinoma (iii) squamous neoplasm (iv) basal cell carcinoma, and (v) neuroendocrine tumor according to 2016 WHO classification [29]. Furthermore, the cBioportal (https:/ / www.cbioportal.org/, accessed on 15 March 2021) database [31,32] calculated the published data on PCa from 15 studies with 2325 patients 
and found a total of 2317 mutations in the gene responsible for developing 4 categories of PCa [33-47] (Table 1).

Table 1. Types of prostate cancer based on cBioportal database [48].

\begin{tabular}{ccccc}
\hline Serial Number & Prostate Cancer Types & Frequency & Frequently Mutated Top 3 Genes & Age (Years) \\
\hline 1 & Prostate Adenocarcinoma & $94.9 \%$ & TP53 (26.5\%), SPOP (9.6\%), FOXA1 (8.5\%) & $61-65$ \\
2 & Castration-Resistant Prostate Cancer & $2.7 \%$ & TP53 (17.1\%), TTN (15.7\%), SPOP (15.7\%) & NR \\
3 & Prostate Neuroendocrine Carcinoma & $2.1 \%$ & TP53 (33.3\%), FOXA1 (16.7\%), RB1 (16.7\%) & NR \\
4 & Prostate Small Cell Carcinoma & $0.3 \%$ & RB1 (57.1\%), APC (42.9\%), BRCA2 (42.9\%) & NR \\
\hline
\end{tabular}

TP53: Tumor Protein P53; SPOP: Speckle-type pox virus and zinc finger protein; FOXA1: Forkhead box protein A1; TTN: Titin; RB1: Retinoblastoma; APC: Adenomatous polyposis coli; BRCA2: Breast cancer 2; NR: Not reported.

Whole-genome sequencing of 292 PCa patients found the maximum mutation in the TP53 gene [33]. On the other hand, whole-exome sequencing showed that the MUC4 gene was found to be mostly mutated (40\%) in metastatic PCa [37]. Among the four types, the most frequently occurred type is prostate adenocarcinoma [40-43,45]. In metastatic prostate adenocarcinoma, the survival rate of the patients was only $11 \%$ where TP3, RYR3, and TTN are the most frequently mutated genes [35]. The pattern of mutations is directly linked with the survival of patients [36]. Overall, the short survival time is linked with the late diagnosis of PCa due to heterogeneity and long latent phase $[49,50]$. Conventional methods are unable to detect PCa in the early stage and have some major limitations [10]. Furthermore, numerous treatment strategies e.g., hormone therapy, prostatectomy, chemotherapy, and radiation therapy were applied to treat the metastatic PCa results in a lower survival rate (11-12\%) of patients [35]. Thus, for early diagnosis and effective treatment of $\mathrm{PCa}$, advanced methods and theranostic agents were in demand to increase the survival rate of patients.

\section{Diagnosis and Detection of Prostate Tumor Cells}

Magnetic nanoparticles including IONPs-based cancer diagnosis strategies have shown promises in diagnosis of early to metastatic stages of PCa [51,52]. The IONPs modified with aptamers, antibodies, biocompatible polymers, and ligands for cell surface receptors have already displayed promise in microscopy, enzyme-linked immunosorbent assay (ELISA), or MRI-based diagnosis of PCa with reliable accuracy, specificity, sensitivity, and reproducibility (Table 2).

\subsection{Detection of Overexpressed Receptors}

Luteinizing hormone-releasing hormone receptor ((LHRH-R) and urokinase-type plasminogen activator receptor (uPAR) are widely expressed cell surface proteins on PCa cells. About $86 \%$ of PCa patients express LHRH receptor mRNA [53,54]. Therefore, both of the receptor proteins act as a potential biomarker for PCa detection [53]. A multifunctional double-receptor-targeting IONPs, LHRH-AE105-IONPs were developed to target both receptors (LHRH-R and uPAR) on PC-3 cells. This drug delivery system bound, accumulated, and internalized more efficiently than non-targeted IONPs into the human prostate carcinoma PC-3 cells confirmed by Prussian blue staining and T2 MRI contrast effects. T2 values of LHRH-AE105-IONPs were significantly decreased about 4 times in LHRH-AE105-IONPs internalized PC-3 cells than single-targeted IONPs accumulated PC-3 cells [26]. Similarly, gastrin-releasing peptide (GRP) receptors belong to a family of seven transmembrane domains [55]. Overexpression of GRP receptors is also found on PCa cells that provided targets for imaging to detect PCa in the early stage [56]. Martin et al. developed a magnetic resonance imaging probe for PCa diagnosis [56]. The probes were conjugated with pan-bombesin analog [b-Ala11, Phe13, Nle14] bombesin-(7-14) and dye-functionalized superparamagnetic IONPs. These peptide-functionalized IONPs were specifically bound and selectively taken up by PC-3 cells through GRP receptors. As a 
result, it can be used not only for the diagnosis of PCa but also as an effective carrier for the drug delivery system [56].

Folate receptors are membrane-associated glycoproteins that are uncommon or rarely expressed in normal cell surfaces [57]. However, the overexpression of folate receptors is reported in a variety of cancers including PCa [57-59]. Therefore, folic acid (FA) conjugated IONPs could be used to diagnose PCa. Previously, FA coated IONPs have been reported in targeting of PCa metastases in lymph nodes. Additionally, prostate-specific membrane antigens (PSMA) are usually expressed on the surface of some PCa cell lines, e.g., 22Rv.1 (low expression) and LnCaP (high expression) while RWPE-1 and PC 3 cells are well known as PSMA-negative PCa cell lines. FA can enter these PSMA-positive cell lines via PSMA receptors [60]. Thus, the surface charge (negative) and hydrodynamic size (approximately $100 \mathrm{~nm}$ ) of FA-IONPs made it suitable to enter and retained inside of PSMA-positive PCa cells in large amounts including lymph node metastases for MRI detection. The R2 value of FA-IONPs was two times lower and R2/R1 ratio was found to be $60 \%$ higher compared to uncoated IONPs. An additional advantage of FA-IONPs is that they can be used to detect, target, and treat other cancer cells expressing folic acid receptors (FAR) on their surface. However, cell lines such as RWPE-1 that do not express PSMA have been found to uptake a small amount of FA-IONPs [60]. Similarly, flavin mononucleotide coated ultrasmall superparamagnetic iron oxide nanoparticles (FLUSPION) specifically targeted riboflavin receptors and accumulated into PCa cells at a significantly higher rate than ultrasmall superparamagnetic iron oxide nanoparticles (USPION) after subcutaneous administration into LnCap tumor xenografts [61]. The R2 relaxation rate of FLUSPION accumulated cells was higher $\left(11.29 \pm 1.64 \mathrm{~s}^{-1}\right)$ than USPION accumulated PCa cells. FLUSPION also accumulated in tumor endothelial cells and tumor-associated macrophages. Therefore, it is an efficient approach to diagnose and treat PCa. However, the accumulation of FLUSPION in the liver, spleen, lung, and skin are the major concerns in their clinical applications [61].

\subsection{Antibody and Polypeptide-Based Detection}

Prostate stem cell antigen (PSCA) is an anchored cell surface protein belonging to the Thy-1/Ly-6 family composed of glycosylphosphatidylinositol (GPI) [62]. In 90\% of primary PCa, PSCA overexpression was detected. It was essential for clinical staging and marking of invasion area e.g., seminal vesicle, prostate capsule, respectively [62,63]. Farahani et al. developed an antibody-binding nanoparticle against PSCA for PCa diagnosis [64]. The major challenge was maintaining the ability of antibodies to bind with antigens. Shahrab and colleagues conjugated dextran (dex) superparamagnetic iron oxide nanoparticles (SPION) with anti-PSCA antibodies to produce an anti-PSCA antibody-dex-SPION for PCa biomarker detection. The labeled PC-3 cells produced strong blue color after anti-PSCA antibody-dex-SPION binding. The intensity of the blue color (resolution) was observed to be higher with a smaller size ( $20 \mathrm{~nm}$ in diameter) of dex-SPION than a larger one $(100 \mathrm{~nm})$. The color intensity verified the efficient binding of anti-PSCA antibody-dex-SPION $(20 \mathrm{~nm})$ on the cell surface with improved imaging and targeting ability than dexSPION [64].

Similarly, PSMA can be a suitable choice that is expressed in the prostate 100 times higher than normal tissues. The specificity of PSMA is higher than prostate-specific antigen (PSA) $[65,66]$. It is also expressed in different stages and grades about 10-fold in PCa patients [66,67]. Deimmunized mouse monoclonal antibody (J591) can target PCa including metastases with high sensitivity and specificity, non-immunogenicity, compatibility, minimum level of nonspecific organ targeting [68,69]. Thus, deimmunized mouse monoclonal antibody (J591) can be a suitable choice for effective detection and therapeutic tool for targeting PSMA-positive PCa cells [70]. Molday ION Rhodamine-B Carboxyl (MIRB), a commercially available IONPs, conjugated with muJ591 antibody (murine derived) for targeting PSMA expressed PCa. The muJ591: MIRB complex inhibited the proliferation and adhesion of PSMA-positive LNCaP cells. Therefore, muJ591: MIRB could be used to target and MR contrast agent to diagnose PSMA-positive PCa cells [71]. Furthermore, Abdolahi et al. constructed specific MR molecular imaging probes using J591 monoclonal 
antibody to diagnose PCa in the early stage [72]. J591-antibody was conjugated with SPION to form J591-SPION. J591-SPION binds specifically to the extracellular domain of PSMA of LNCaP. J591-SPION binding increased the imaging quality with high sensitivity and stability. It also reduced the image intensity by $95 \%$ in PSMA-positive LNCaP cells compared to the $14 \%$ reduction in DU145 cells (PSMA-negative) with the same Fe concentration $(80 \mu \mathrm{g} / \mathrm{mL})$. These findings confirmed the potentiality of J591-SPION as an MR contrast agent in PCa diagnosis [72]. Another PSMA-targeting magnetic nanoparticles (MNPs) MNPs was formulated by the conjugation of biocompatible iron oxide magnetic nanoparticles and J591 to construct J591-MNP. J591-MNP was injected intravenously to mice with severe combined immunodeficiency (SCID) mice that were specifically bound to the PSMA without affecting PCa cell viability and increased magnetic resonance contrast of tumors to detect/localize PCa [73]. Zhu and his colleagues conjugated a PSMA-targeting CQKHHNYLC polypeptide with SPION to produce PSMA-targeting molecular MRI contrast agents [74]. The polypeptide-SPION increased MRI signal significantly at $6 \mathrm{~h}$ of post-injection in tumor-bearing mice. According to this study, the concentration of $\mathrm{Fe}_{3} \mathrm{O}_{4}$ was $0.240 \mathrm{mg} / \mathrm{mL}$ that was subcutaneously administered to the xenograft model. It heterogeneously deposited inside of the tumor cells both in vivo and in vitro that provided contrast image in MRI scan. However, PSMA-targeting polypeptide-SPION deposited in the spleen and slightly entered the liver but were not observed in the kidney or other organs (Figure 2) [74]. Moreover, SPON (50 nm) were conjugated with a water-soluble graft copolymer, methoxyl polyethylene glycol (mPEG-OH) grafted onto polyethyleneimine (hy-PEI) to construct a nano complex called mPEI-g-PEG-SPION [75]. Following grafting, a single-chain monoclonal antibody against prostate stem cell antigen (PSCA) was coated with mPEI-g-PEG-SPION to form a single-chain antibody functionalized nanoprobe (scAbPSCA-PEI-g-PEG-SPION). This small nanoprobe specifically entered the PCa cells in vitro and reduced the T2 MRI signal intensity to $44.76 \%$ that showed the efficiency of this MRI nanoprobe to detect PCa in its early stage. scAbPSCA-PEI-g-PEG-SPION was found to be advantageous showed some advantages over naked SPION such as lower level of toxicity, higher transfection rate, and enhanced imaging effects, respectively [75].
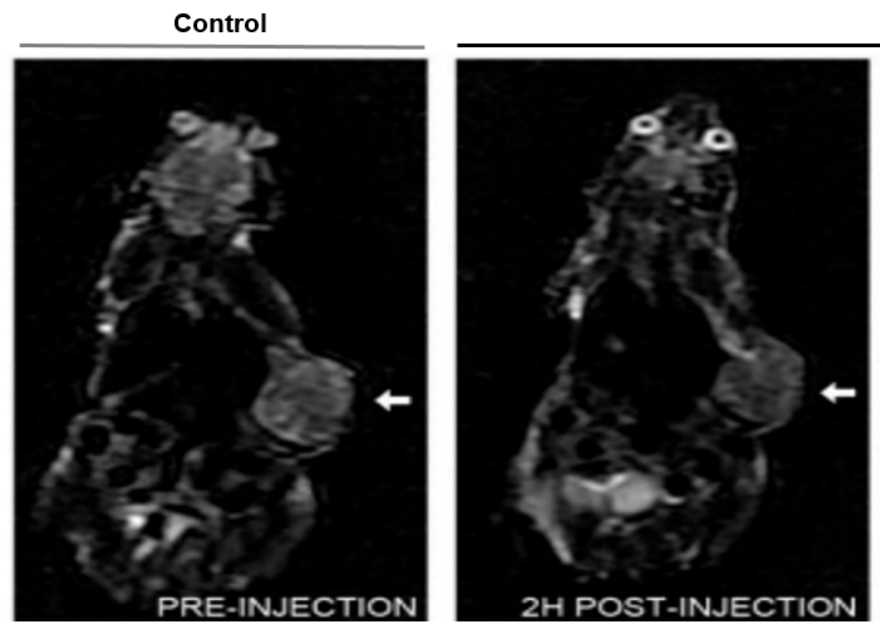

SPIONs Treatment

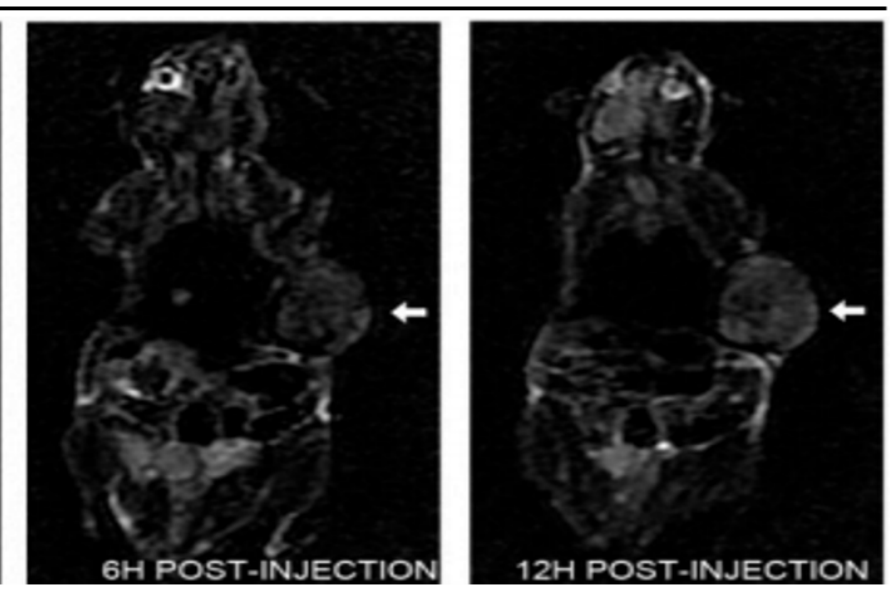

Figure 2. MRI images of PSMA-expressing tumor-bearing mice. T2 MRI signals reduced in PSMA-expressing LNCaP tumor following polypeptide-SPION administration $(0.240 \mathrm{mg} / \mathrm{mL})$. These experimental images were adapted from Yunkai et al. [74]. This study has been published under the Creative Commons Attribution License which permits unrestricted use, distribution, and reproduction in any medium, provided the original work is properly cited. SPION: Superparamagnetic iron oxide nanoparticles; Arrow $(\rightarrow)$ : Lymph Node Carcinoma of the Prostate (LNCaP tumor).

An electroconductive interface was developed by Farshchi et al. in order to amplify the signal of the substrate during antigen-antibody binding in the electrochemical analysis for PCa early diagnosis [76]. First, spherical iron oxide magnetic nanoparticles $\left(\mathrm{Fe}_{3} \mathrm{O}_{4}\right)$ were combined with biotinylated-anti-prostate-specific antigen (PSA) antibody on a glassy 
carbon electrode (GCE). Bovine serum albumin (BSA) was combined with the nanoparticleantibody complex to prevent any nonspecific binding. Secondly, HRP-conjugated antibody, HRP-Ab2 (secondary antibody) coated on gold nanoparticles (AuNPs). PSA was sandwiched by the immunoreaction of primary (Ab1) and secondary antibody (Ab2) and emitted light. This emission of signals from the substrates was captured by the immunosensor by transmission electron microscopy. It should be noted that the immunosensor showed higher sensitivity ( 0.001 to $1 \mu \mathrm{g} / \mathrm{L}$ of PSA) due to excellent electrical conductivity, fast electron transfer, good catalysis properties, and desirable biocompatibility of the substrate. This magneto-immunosensor-based bioassay created a new possibility to detect multiple proteins at a time using multiple inorganic metal nanoparticle tracers in early PCa diagnosis [76]. Another antibody-based PCa identification method was developed by Zhang and colleagues. [77]. IONPs were fabricated with anti-PSA antibody followed by the probe immobilization on gap-fingered electrode sensing surface. During this experiment, spiking of PSA in human serum continued and the interaction between PSA and anti-PSA antibody was unaffected. This continuous antigen-antibody binding represented the efficiency and sensitivity (1.9 pg/mL of PSA in human serum) of this method for early PCa diagnosis [77].

\subsection{Detection of Physiological Metabolite}

Sarcosine (N-methyl glycine; $\mathrm{CH}_{3} \mathrm{NHCH}_{2} \mathrm{COOH}$ ) is a regular physiological metabolite and a non-protein amino acid enzymatically synthesized from dimethylglycine. Normally, the concentration of sarcosine in human (men) blood serum is $1.4 \pm 0.6 \mu \mathrm{M}$. However, in diseased conditions (e.g., sarcosinemia, PCa) sarcosine level is elevated [78,79]. Sarcosine acts as a prospective mediator in PCa development [80]. Uhlirova et al. developed chitosan (CS), and sarcosine oxidase (SOX) modified SPION to detect the level of sarcosine for PCa diagnosis [81]. Three types of modified SPION were formulated and characterized, SPIONAuNPs (100-300 nm), SPION-CS-AuNPs (300-700 nm), and SPION-CS-SOX-AuNPs (600$1500 \mathrm{~nm}$ ), respectively. After formulation, toxicity was tested in yeast (S. cerevisiae) and microorganisms (E. coli and S. aureus). Half maximal inhibitory concentration $\left(\mathrm{IC}_{50}\right)$ of SPION-AuNPs was 5.1 to $7.6 \mathrm{mg} / \mathrm{mL}$ for each of the models where $\mathrm{IC}_{50}$ of AuNP was shown to be $15 \mu \mathrm{g} / \mathrm{mL}$. Moreover, CS and SOX modified SPION demonstrated IC $\mathrm{IC}_{50}$ value in yeast 17.9 and $36.1 \mathrm{mg} / \mathrm{mL}$, respectively. Additionally, SPION-CS-SOX-AuNPs exhibited five times lower toxicity to human erythrocytes than non-modified SPION-AuNPs. Here, pseudo-peroxidase activity of SPION-AuNPs was used to increase the sensitivity. This procedure could be used to detect sarcosine at a very low (micromolar) and monitor the progress of PCa. This technique is also cheap, simple, affordable, and convenient for screening tests and telemedicine applications [81].

\subsection{Detection of Metastases}

PCa metastasis can be graded based on their spread in the lymph nodes $[82,83]$. Alexander et al. used a handheld magnetometer with SPION to detect SLNs in PCa [84]. It was the first magnetometer-guided sLND study conducted to detect PCa by SPION. Intraprostatic SPION were injected in 20 patients of both intermediate and high-risk PCa one day earlier of magnetometer-guided sentinel lymphadenectomy (sPLND) and extended pelvic lymph node dissection (ePLND) in association with radical prostatectomy. The detection rate was almost $94 \%$. Though it was proved to be advantageous for its simplicity, safety (non-radioactive hazards), and reliability, a limited number of patients were included in this study without MRI and the detection rate was also below 95\% [84]. However, MRI-based techniques provided extra benefits to detect and characterize $\mathrm{PCa}$ in the early stage [27]. In 2018, Alexander and his team carried out another study by magnetometer-guided sLND using SPION to diagnose PCa [85]. This time, 50 patients (both intermediate and high-risk $\mathrm{PCa}$ ) were included following the same procedure, but the lymph nodes selected for magnetometer-guided sLND were also visualized by MRI. The detection rate and accuracy were approximately $100 \%$ with the minimum concentration of PSA $\geq 10 \mathrm{ng} / \mathrm{mL}$. It was also successfully applied to detect breast cancer and to defeat 
the limitations of the radioisotope-based sentinel procedure. This study also confirmed the efficiency of imaging techniques especially MRI for PCa diagnosis [85]. Previously, Li, Chao-Shiang et al. used USPION as a contrast agent in MRI to detect PCa in the primary stage [86]. In this study, 60 patients were included where central zones (CZ) and peripheral zones (PZ) of prostate were assayed by T2- and T2*-weighted MRI in association with USPION-enhanced MRI. As the signal-to-noise ratios (SNRs) decreased significantly in CZ than PZ and it was concluded that USPION administered prostate gland may be associated with primary PCa [86].

Triantafyllou et al. investigated the accuracy of USPION in MRI-based diagnosis of PCa metastases [87]. After the intravenous administration of USPION in 48 PCa patients, the lymph nodes (LNs) were examined with two similar pelvic MRI scans. MRI scans demonstrated the efficiency diagnosis (accuracy 77.3\%) of PCa and facilitated the specification of PCa treatment strategies. However, it was eligible only to detect metastatic LNs with a minimum diameter of $\geq 5 \mathrm{~mm}$ and were unable to diagnose $<3 \mathrm{~mm}$. Furthermore, some adverse effects e.g., urticarial, hot flashes, hypertension, headache, swelling of neck and nose, and diarrhea was observed in $11 \%$ of patients [87]. Similarly, diagnosis of lymph node metastases in the early stage was also done by USPION-contrast MRI since it showed higher sensitivity than positron emission tomography (PET) [88]. After the collection of patient history, a simultaneous/sequential boost to USPION (+) nodes were provided in patients who received androgen deprivation therapy for $>6$ months in association with external beam radiation to integrated nodal basins. Results showed that all the patients $(n=69$, median age $=62$ ) had USPION in their lymph nodes and received USPION-guided radiation beam therapy. This study confirmed that USPION-based radiation therapy was feasible and well-tolerated in patients $(n=69)$ with predominantly recurrent PCa [88]. Sterenczak and colleagues examined SPION and manganese chloride $\left(\mathrm{MnCl}_{2}\right)$ as MRI contrast agents to diagnose PCa [27]. CT1258 cells (PCa cells) and CT1258 tumor-bearing NOD-SCID mice were used for in vitro and in vivo studies, respectively. In vitro and in vivo experimentations were carried out using $1 \mathrm{~T}$ MRI and $7 \mathrm{~T}$ MRI, respectively after labeling with the MRI contrast agents. In vitro detection limit was $10^{5} \mathrm{CT} 1258$ cells while in vivo detection limit was $10^{3}$ and $10^{4}$ cells for SPION and $\mathrm{MnCl}_{2}$, respectively. Interestingly, $\mathrm{MnCl}_{2}$ labeled cells in NOD-SCID mice were detectable for longer period of time (4-16 days) than SPION labeled cells (until 4 days). This method also allows measurement of actual volume of tumor at different time points, hence these contrast agents could be used to monitor the prognosis of PCa [27]. Poly-l-lysine (PLL) is a transfection agent. Previously, an in vitro study was conducted where SPION were used in the presence or absence of poly-l-lysine (PLL) for PCa diagnosis [89]. MRI study confirmed that $42-126 \mu \mathrm{g} / \mathrm{mL}$ of PLL conjugated SPION could label human PCa cells following 12-24 h incubation. Though PLL-coated SPION showed no toxicity with their simplicity, and efficiently labeled tumorigenic PCa cells in vitro, but in vivo study is still needed to confirm these activities [89]. Figure 3 shows a representative image of IONPs mediated PCa diagnosis. 


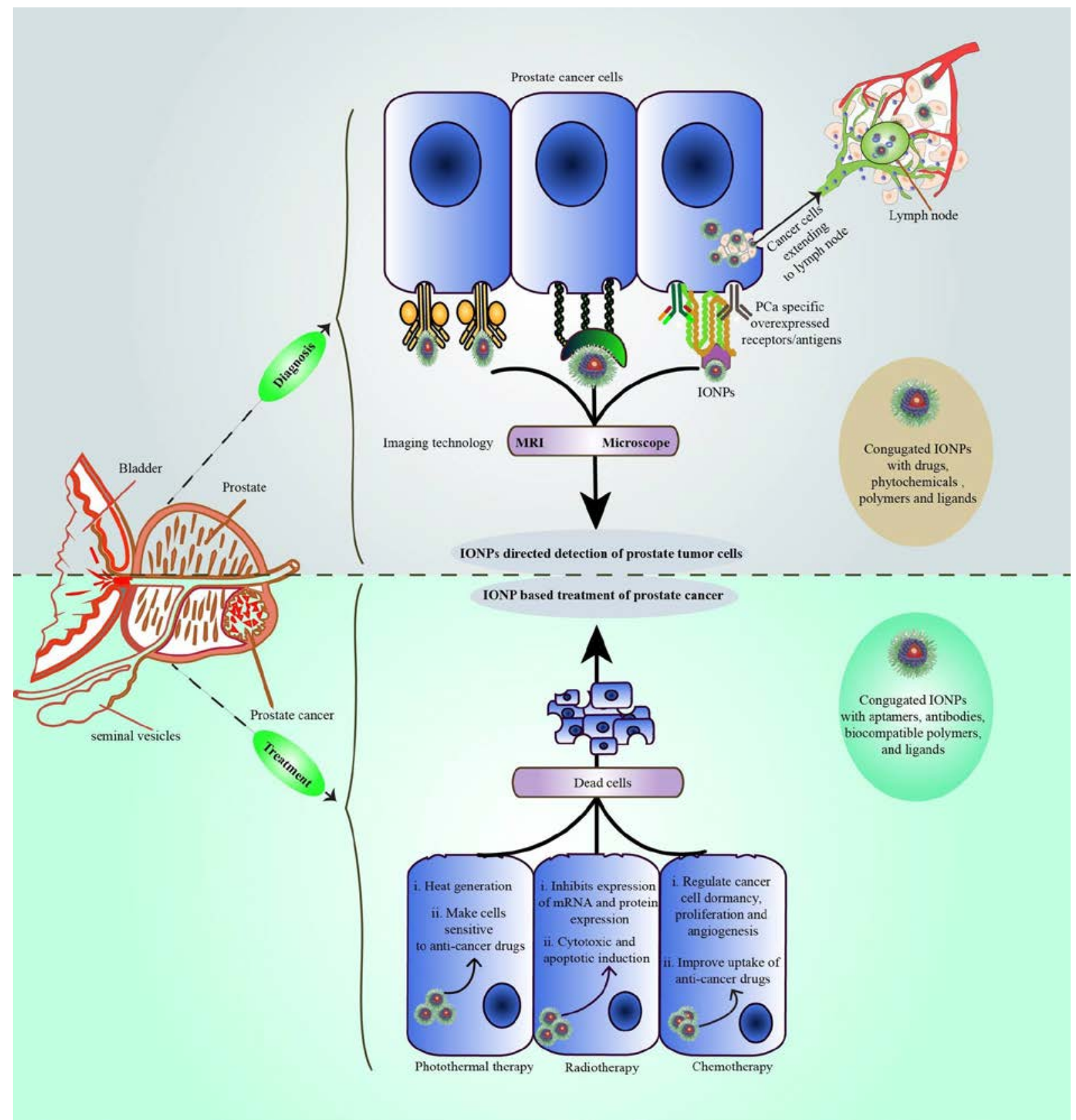

Figure 3. Diagnosis and treatment of prostate cancer using surface-modified iron oxide nanoparticles. IONPs coated or conjugated with drugs, phytochemicals, polymers, and ligands for diagnosis and aptamers, antibodies, biocompatible polymers, and ligands for various treatment approaches e.g., photothermal therapy, radiotherapy, chemotherapy. IONPs: Iron oxide nanoparticles; PCa: Prostate cancer.

\subsection{Others}

The R11 peptide is a poly (11)-arginine that displayed organ-specific uptake in bladder and prostate tissues. Hence, it was used as a suitable drug delivery vehicle for bladder and PCa diagnosis and therapies [90]. Wadajkar et al. assembled IONPs (average diameter of $100 \mathrm{~nm}$ ) with thermo-responsive poly-N-isopropyl acrylamide-acrylamide-allylamine and conjugated with R11 peptides [91]. After $24 \mathrm{~h}$ of incubation in vitro with normal PCa cells, R11-conjugated PMNPs (R11-PMNPs) showed compatibility with a concentration up to $500 \mathrm{mg} / \mathrm{mL}$ and a higher level of accumulation in PCa cells (e.g., PC-3 and LNCaP) than non-conjugated PMNPs. In vivo studies also showed that R11-PMNPs deposition in tumors was higher than other major organs and demonstrated to be suitable for PCa 
detection and treatment process. Additionally, both the R11 peptide and R11-PMNPs were found to be safe for normal cells that raised their potentiality as a PCa specific drug delivery system [91].

Table 2. Prostate cancer diagnosis using iron oxide nanoparticles.

\begin{tabular}{|c|c|c|c|c|c|c|}
\hline $\begin{array}{l}\text { Types of } \\
\text { IONPs }\end{array}$ & $\begin{array}{c}\text { Coating/Hybridizing } \\
\text { Material }\end{array}$ & Test Specimen & Target Receptor & $\begin{array}{c}\text { Imaging } \\
\text { Technique }\end{array}$ & $\begin{array}{c}\text { Detection (Lower) } \\
\text { Limit }\end{array}$ & Ref. \\
\hline IONP & $\begin{array}{l}\text { PTX, LHRH peptide, } \\
\text { AE105 peptide }\end{array}$ & $\begin{array}{l}\text { RC77T/E and } \\
\text { RC77N/E }\end{array}$ & $\begin{array}{l}\text { LHRH-R and } \\
\text { uPAR }\end{array}$ & MRI & NR & [26] \\
\hline SPION & PBA & PC-3 & GRP-R & MRI & $10^{3}$ cells & [56] \\
\hline IONP & FA & RWPE-1 and PC-3 & FA-R & MRI & NR & [60] \\
\hline FLUSPION & FM & $\begin{array}{l}\text { LnCap tumor } \\
\text { xenografts, } \\
\text { HUVEC }\end{array}$ & Rf-R & MRI & $2 \times 10^{6}$ cells & {$[61]$} \\
\hline SPION & anti-PSCA Ab & PC -3 cells & PSCA-R & ELISA and WB & $70 \mu \mathrm{g} / \mathrm{mL}$ & {$[64]$} \\
\hline IONP & muJ591-Ab & $\begin{array}{l}\text { LNCaP and } \\
\text { DU145 }\end{array}$ & PSMA & MRI & NR & {$[71]$} \\
\hline SPION & $\mathrm{J} 591-\mathrm{Ab}$ & LNCaP, DU145 & PSMA & MRI & NR & [72] \\
\hline IONP & $\mathrm{J} 591-\mathrm{Ab}$ & $\begin{array}{c}\text { LNCaP, PC-3, } \\
\text { DU145, and SCID } \\
\text { mice }\end{array}$ & PSMA & MRI & NR & [73] \\
\hline SPION & CQKHHNYLC & $\begin{array}{l}\text { LNCaP, PC-3 and } \\
\text { LNCaP } \\
\text { tumor-bearing } \\
\text { mice }\end{array}$ & PSMA & MRI & $0.240 \mathrm{mg} / \mathrm{mL}$ & {$[74]$} \\
\hline SPION & $\mathrm{scAb}_{\mathrm{PSCA}}$-PEI-g-PEG & $\begin{array}{c}\text { PC-3, PC3M, and } \\
\text { NIH3T3 }\end{array}$ & PSCA & MRI & $40 \mu \mathrm{g} / \mathrm{mL}$ & {$[75]$} \\
\hline IONP & Anti-PSA Ab & Human Serum & PSA-R & TEM & $0.001 \mu \mathrm{g} / \mathrm{L}$ PSA & [76] \\
\hline IONP & Anti-PSA Ab & Human Serum & PSA-R & IDE surface & $1.9 \mathrm{pg} / \mathrm{mL}$ (PSA) & {$[77]$} \\
\hline SPION & CS, SOX & Yeast cell, RBCs & NR & SEM & NR & [81] \\
\hline SPION & NR & 20 PCa patients & SLN & MRI & 9.84 ng/mL (PSA) & [84] \\
\hline SPION & NR & 50 PCa patients & SLN & MRI & $>10$ ng/mL (PSA) & [85] \\
\hline USPION & NR & NR & PSA & MRI & $\begin{array}{c}18.8 \pm 30.5 \mathrm{ng} / \mathrm{mL} \\
(\mathrm{PSA})\end{array}$ & [86] \\
\hline USPION & NR & NR & PLN & MRI & $\begin{array}{l}2.6 \mathrm{mg} \text { iron } / \mathrm{kg} \text { body } \\
\text { weight of USPION }\end{array}$ & [87] \\
\hline USPION & NR & NR & $\begin{array}{c}\text { Lymph } \\
\text { nodes/PSA }\end{array}$ & MRI & NR & {$[88]$} \\
\hline SPION & NR & CT1258 & NR & MRI & $\begin{array}{c}10^{3} \text { and } 10^{4} \text { cells per } \\
\text { tube }\end{array}$ & [27] \\
\hline SPION & Cdex, PLL & PC-3 & NR & NR & $2 \times 10^{5}$ cells $/ \mathrm{mL}$ & [89] \\
\hline IONP & PIAA & PC-3 and $\mathrm{LNCaP}$ & R11-R & MRI & 5000 cells/well & [91] \\
\hline
\end{tabular}

PCa: Prostate cancer; IONP: Iron oxide nanoparticle; PBAB: Pan-bombesin analog [b-Ala11, Phe13, Nle14] bombesin-(7-14); FM: Flavin mononucleotide; RF-R: riboflavin receptors; SPION: Superparamagnetic iron oxide nanoparticle; SLN: Sentinel lymph node; MRI: Magnetic resonance imaging; Ab: Antibody; WB: Western Blotting; PSA: Prostate-specific antigen; CT1258: Canine prostate cell line; SPION: Superparamagnetic iron oxide nanoparticles; SPIO-PLL: Superparamagnetic iron oxide-poly-l-lysine; PC3: Human prostate cancer cell lines; TEM: Transmission electron microscopy; CS: Chitosan, SOX: Sarcosine oxidase; RBCs: Red blood cells; LHRH-R: Luteinizing hormone-releasing hormone receptor; uPAR: Urokinase-type plasminogen activator receptor; RC77T/E and RC77N/E: Immortalized prostate cancer cell lines; CQKHHNYLC: PSMA-targeting polypeptide; LNCaP: PSMA-positive prostate cancer cell lines; SEM: Scanning electron microscopy; PSMA: Prostate-specific membrane antigen; PSCA: Prostate stem cell antigen; USPION: Ultrasmall superparamagnetic iron oxide nanoparticles; PLN: Pelvic lymph nodes; Cdex: Carboxydextran; ELISA: Enzyme-linked immunosorbent assay; GRPR: GRP receptor; FA: Folic acid; FAR: Folic acid receptor; PIAA: Poly-N-isopropyl acrylamide-acrylamide-allylamine; LNM: Lymph node metastases prostate cancer cells; HUVEC: Human umbilical vein endothelial cells; NR: Not reported. 


\section{IONP-Based Treatment of Prostate Cancer}

IONPs are conjugated with drugs, phytochemicals (natural anticancer agents), other polymers, and ligands that made them suitable for PCa treatment where many resistant drugs e.g., Docetaxel (DTX) became functional. IONP-based treatment approaches including photothermal therapy [92], radiotherapy [93], chemotherapy [26], bioactive compounds-based nanotherapy [94], and hyperthermia [60] can be used as an alternative to conventional therapy (Table 3 and Figure 3).

\subsection{Photothermal Therapy}

Photothermal therapy (PTT) uses near-infrared light for efficient heat production (hyperthermia) in tumor cells resulting in cancer cell death by irreversible apoptosis [95]. IONPs mediated PTT has become a reliable window for PCa treatment [92]. Herein et al. conducted a comparative study between magnetite/maghemite nanospheres and nanoflowers to find out the efficiency of IONPs in PCa treatment by PTT and magnetic hyperthermia (MHT) [92]. PC3 human PCa cells were incubated for $30 \mathrm{~min}$ with the four magnetic nanoparticle formulations (magnetite nanospheres, maghemite nanospheres, magnetite nanoflowers, and maghemite nanoflowers). Magnetite nanoflowers of IONPs internalized with a higher concentration (5 to 6 times more than nanospheres) resulting in $60 \%$ PC 3 cell death by necrosis and $20 \%$ by apoptosis at a lower dose ( $36 \mathrm{mg}$ Fe/L). Furthermore, the magnetite nanoflowers reduced cell viability close to zero where more than $60 \%$ viable cells were present at the same concentration of maghemite nanoflowers. However, a higher concentration is needed to reach saturation in PTT, therefore if a higher temperature is needed magnetic nanoparticle-based hyperthermia could be a good option than PTT [92].

\subsection{Radiotherapy}

In radiotherapy (RT), fractionated focal irradiation is used to treat cancer patients [96]. Normally, for cancers with low and intermediate-risk, RT is used as an alternative therapeutic tool to control locally advanced cancer instead of surgery [97] or PCa patients who received radical prostatectomy [98]. 5-fluorouracil (5-FU) is an analog of uracil and is also used as a potent anticancer agent. 5-FU can be converted into fluorodeoxyuridine monophosphate that irreversibly inhibits thymidylate synthase in mammalian cells. Another study revealed that 5-FU can be misincorporated into the DNA and ribonucleic acid (RNA) thus inhibits the expression of cancer-causing mRNA and protein [99]. The combination of 5-FU with other conjugates made it more efficient to penetrate the target cell for cytotoxic and apoptotic induction [100]. Hajikarimi et al. formulated magnetic poly lactic-co-glycolic acid (PLGA)-coated IONPs as a carrier of 5-FU. Both the 5-FU and 5-FU loaded nanoparticles were applied on DU 145 cells for 24 h [93]. Cellular uptake of nanoparticles was recorded by atomic absorption spectroscopy (AAS) that showed an increment of the cellular uptake of 5-FU loaded nanoparticles. This entry resulted in an alleviation of the proliferation capacity of DU 145 cells. Similarly, a combination of 5-FU loaded nanoparticles with $2 \mathrm{~Gy}$ of megavoltage $\mathrm{X}$-ray radiation decreased the colony number much more efficiently (two times) than free 5-FU [93].

\subsection{Chemotherapy}

Chemotherapy (CT) is a common treatment option for PCa; however, lack of specificity, drug-induced side effects, and resistance of drugs are the prominent drawbacks of this therapeutic approach [101]. Patients receiving CT with metastatic castration-resistant prostate cancer (mCRPC) have also been demonstrated to prolong life span [102].

Recently, docetaxel (DTX), cabazitaxel, paclitaxel (PTX), and doxorubicin are widely used as chemotherapeutic agents [102-104]. However, many side effects of CT such as detrimental effects on hair follicles, immune system gastrointestinal tracts, and major body organs as well as hemorrhage and drug resistance are the major concerns $[105,106]$. Recently, magnetic nanoparticles (e.g., IONPs) coated with biocompatible polymers and targeted drugs have opened a new era in cancer therapeutics to overcome these side 
effects $[26,104]$. For instance, IONP was encapsulated with PTX. This encapsulation prevents PTX from degradation in the blood circulation that increased the pharmacokinetic efficiency and better patient outcome with a limited level of toxicity in the circulatory system. Furthermore, LHRH peptide and AE105 peptide-coated IONPs specifically target PC3 cells, which facilitates internalization and accumulation of LHRH-AE105-IONPs-PTX more efficiently, therefore enhancing PC3 cells cytotoxicity by two times compared to non-targeted IONPs. This phenomenon also reduced the use of PTX amount by 10 times to achieve similar cytotoxic effects produced by the free drugs to the PC-3 cancer cells. Finally, this nanoformulation provided a substitute for PCa therapeutics with a better quality of life and longevity of patients [26].

DTX is another anticancer drug approved by Food and Drug Administration (FDA) used to treat several cancers, including PCa [107]. However, DTX becomes resistant in clinical oncology [108]. As a result, it was essential to find out a drug delivery system to make it functional again to its site of action. To pursue the target, a (DTX) loaded PSMA targeted superparamagnetic iron oxide nanoparticle (J591-SPION-DTX) was formulated [109]. J591-SPION-DTX efficiently binds with $\beta$-tubulin and inhibited the expression of chemo-resistance-associated proteins (MDR1). Conversely, expression of apoptosisassociated proteins (Bax, Bad, cleaved poly (ADP-ribose) polymerase (PARP), caspase 3 ) increased in PSMA-positive cells than PSMA-negative cells [109]. Furthermore, microRNA (miRNA)-based diagnosis and treatment of PCa has already been demonstrated in its theranostic approach to overcome the limitation of DTX resistance [110]. A nanocomplex (MPEI-PEG NPs) was developed by Nagesh et al. through the conjugation of an iron oxide core with polyethyleneimine-polyethylene glycol (PEI-PEG) and subsequent binding to the miR-205. Efficient cellular uptake of miR-205-NPs in C4-2 and PC-3 cells showed growth retardation of $\mathrm{PCa}$ [107]. Studies showed that miR-205 inhibits the antiapoptotic protein BCL-xL and down-regulates Bcl-w proteins and induces apoptosis of PCa cells [111]. PCa cells overexpressing miR-205 also restored the anticancer activity of DTX by inactivating MDR1 protein. Therefore, DTX became chemosensitized again. In colony formation assay, a combination of DTX with miR-205-NPs demonstrated greater efficiency to decline the number of C4-2 and PC-3 cell colonies by approximately $40 \%$ compared to the non-treated and DTX alone. This combination also inhibited metastatic PCa cells. miR-205-NPs is biocompatible and caused negligible hemolysis ( $5 \%$ hemolysis at the highest concentration, $50 \mu \mathrm{g}$ ) during in vitro analysis. To recapitulate the study, this nanoplatform (a combination of miR-205-MPEI-PEG and DTX) with superior transfection e7fficiency, superior anticancer properties, and chemosensitization can be a better option for chemotherapeutic treatment of PCa than DTX alone [107].

Again, a nanovector for anticancer drugs e.g., doxocurbin (DOX) and DTX was developed for targeted PCa treatment. Singh et al. loaded DOX and DTX on a glutathione disulfide (GSSG) conjugated polydopamine (pDA)-modified IONPs (pDA-IONPs) which can easily penetrate the cells because of their hydrophobic nature [104]. MTS and apoptosis assays confirmed that free drugs were more cytotoxic $\left(\mathrm{IC}_{50}, 1200 \mathrm{nM}\right)$ to the PC-3 cells than drug-loaded nanoparticles in a lower concentration $\left(\mathrm{IC}_{50}, 3400 \mathrm{nM}\right)$. However, free drugs also created some detrimental effects e.g., weakening of the immune system that leads the human body vulnerable to microbial infection, fatigue, slow healing process, etc. However, drug-loaded nanoparticles bound specifically to the PC-3 cancer cells and destroyed them [104].

\subsection{Hyperthermia}

Hyperthermia (also known as thermal therapy) is one of the potent therapeutic options for several cancers, including PCa. Hyperthermia-based therapy kills tumors/malignant cells by elevated temperature ranges from $39^{\circ} \mathrm{C}$ to $45^{\circ} \mathrm{C}$ [112]. However, organ damage by imbalanced overheating, bleeding is the common drawbacks of conventional hyperthermia [113]. IONP-based hyperthermia is an alternative and novel approach for the safe treatment of cancers, including PCa. A novel nanocluster (ZnMn-IONPs) based on a 
systematically delivered magnetic hyperthermic study was conducted [114] to overcome the limitation of intra-tumoral administration of nanoparticles to the PCa site. First, the metal dopants e.g., Zn, Mn were fabricated into the IONPs that increased their efficiency of heating upon exposure to an alternating magnetic field (AMF). For in vitro analysis, human PCa cells (DU145) and non-malignant human embryonic kidney cells (HEK-293) were allowed to incubate for $24 \mathrm{~h}$ with different concentrations of ZnMn-IONPs (50-250 $\mathrm{gg}$ of $\mathrm{Fe} / \mathrm{mL}$ ). Efficient accumulation of the nanoclusters was observed in tumors after intravenous injection into the mice carrying PCa grafts via passive targeting. ZnMn-IONPs elevated the temperature above $42{ }^{\circ} \mathrm{C}$. It significantly killed more than $90 \%$ PCa cells safely without noticeable toxicity to normal cells. However, long-term effects are still needed to be explored. On the other hand, naked IONPs mediated treatment killed only $60 \%$ of PCa cells applying the same condition. [114].

Bioaggregation of IONPs is one of the major challenges to overcome in PCa theranostic [115]. It can cause lower biodistribution, declining heating ability, interrupting visualization and quantification [116]. To overcome aggregation, first, IONPs were coated successfully with an aggregation-resistant mesoporous silica shell. After characterization, IONPs and ms-IONPs were tested both in vitro (a monolayer of PCa cells, LNCaPPro5 with $1.0 \mathrm{mg}$ Fe/mL IONPs or ms-IONPs for the heating experiment) and in vivo (subcutaneously injected on the hind limb of 20-25 g male nude mice with a tumor of average 8 to $10 \mathrm{~mm}$ diameter). It was found that ms-IONPs provided efficient heating capability with strong signal increment in MRI in vivo. Additionally, mesoporous silica-coating provided a protective layer to minimize the toxic effects of nanoparticles towards HDFn human skin fibroblasts as well as smooth surface function, efficient drug loading, and release. This infers that less aggregation of nanoparticles can increase heating efficiency and imaging performance of nanoparticles and ms-IONPs is a new approach to do so in PCa theranostic [116].

\subsection{Phytochemical-Based Therapy}

Phytochemicals are mainly secondary metabolites of plants. Phytochemicals have been found to play an important role in the prevention of PCa by regulating many stressmediated signaling pathways [117]. Chemoprevention of PCa by phytochemicals was found to modulate cell proliferation and apoptosis of the target cell. However, low solubility, poor penetration into cells, high hepatic disposition, and narrow therapeutic index are some limitations of phytochemicals to be used as anticancer agents $[113,118]$. Therefore, a drug delivery system was needed as a carrier of these phytochemicals to function more precisely and efficiently to their target site [118]. Eupatorin (a flavonoid) has a range of phytomedical, tumor suppression, and apoptosis induction activity in multiple cancer cell lines including in the treatment of PCa. Tousi and his collegues developed poly(ethylene glycol) methyl ether-block-poly-lactide-co-glycolide (mPEG-b-PLGA) coated IONPs to act as a carrier for this phytochemical to increase its efficacy [94]. There was a sustainable release of eupatorin over $200 \mathrm{~h}$ with $100 \mu \mathrm{M}$ (DU-145) and $75 \mu \mathrm{M}$ (LNCaP) of IC $_{50}$ concentration. Eupatorin loaded $\mathrm{Fe}_{3} \mathrm{O}_{4} @ \mathrm{mPEG}-\mathrm{b}-\mathrm{PLGA}$ nanoparticles demonstrated a significant reduction of DU-145 and LNCaP cell growth through apoptosis by up-regulating Bax/Bcl2 ratio and the cleaved-caspase 3 level with an entrapment efficacy of $90.99 \% \pm 2.1 \%$. In terms of safety, both free and IONP-conjugated eupatorin were found to be almost safe (displayed negligible toxicity) against HUVECs as normal cells [94].

\subsection{Others}

In castration-resistant prostate cancer (CRPC), disease progression and level of prostatespecific antigen (PSA) continue to increase regardless of androgen deprivation therapy (ADT) [119]. To prevent the continuation of cancer cells even in metastatic conditions, DTX was the next option. However, DTX became resistant to cancer therapeutics, as mentioned earlier [108]. Both of these limitations can be removed by a nanoscopic therapeutic system through the formulation of Wy5a-DTX-SPION [120]. In this nanoformulation, SPION were 
encapsulated by DTX and Wy5a aptamer directed the transport of nanoparticles to the targeted cancer cells. PC-3 cells were incubated with both DTX and DYX-encapsulated nanoparticles, where (DTX-encapsulated) Wy5a-DTX-SPION was significantly more cytotoxic at lower $\mathrm{IC}_{50}$ (1.42-fold and 1.27-fold) than those of non-targeted nanoparticles and DTX, respectively. Xenograft model for in vivo analysis also showed inhibitory effect against tumor with normal level of white blood cell (WBC) count. So this nanoformulation showed enhanced efficacy of CRPC theranostic and low toxicity to the circulation both in vivo and in vitro that make it promising drug delivery system for the efficient treatment of CRPC [120].

You Ling et al. formulated a dual DTX-SPION loaded nanoparticles for the theranostic applications of PCa [121]. DTX-SPION then fabricated with active tumor-targeting singlechain prostate stem cell antigen antibodies (scAbPSCA) to form a multifunctional complex nanoparticle, scAbPSCA-DTX-SPION. This multifunctional nano complex-mediated the entry of NPs and showed antiproliferative activity against PC-3 cell lines in a time and dose-dependent manner. scAbPSCA-DTX-SPION showed the highest antiproliferative activity compared to the DTX at 1.46 and 1.57-fold lower $\mathrm{IC}_{50}$ concentration. This nanoformulation also acts as an MRI contrast agent via PSCA receptors with a high clustering effect. Therefore, it can be used as a multifunctional nano complex to diagnose, treat, and monitor the therapeutic effect of human PCa at a time [121].

It is also known that increased vasculature is obligatory for the metastatic growth of a cancer cell. Thus, a suitable anti-angiogenic therapy can be a great paradigm to inhibit the growth of cancer cells. Though androgen deprivation therapy (ADT) alleviated the suffering of many patients with advanced PCa for $80 \%$ of cases. Montecinos et al. showed that human re-hydrated lyophilized platelet (hRL-P) conjugated SPION inhibited angiogenesis in PCa cells [122]. hRL-P was conjugated with thrombin- and ADP-activated human umbilical vein endothelial cells (HUVEC) following the addition of SPION. hRL-P, and hRL-P loaded with SPION were systematically administered into the primary xenografts of human prostate tissue. It selectively bound to the primary xenografts of human prostate tissue on ADT-damaged human microvasculature that inhibited the angiogenesis to the PCa cells. Thus, it provided us a new approach to treat PCa [122].

$\mathrm{Yu}$ and his team developed an image-guided PCa therapy where thermally crosslinked SPION (TCL-SPION) were coated with (CGA) 7-elongated PSMA aptamers to enhance Dox loading capacity [123]. Dox intercalated into the GC-rich duplex of PSMA aptamer and non-covalently interacts via electrostatic interactions onto the polymeric shell of TCL-SPION to form Dox@Apt-hybr-TCL-SPION. Dox@Apt-hybr-TCL-SPION were specifically internalized to the targeted LNCaP (PSMA-positive) cells by receptormediated endocytosis. The increase in tumor size was significantly reduced in Dox@Apthybr-TCL-SPION treated LNCap by $3.4 \pm 0.6$-fold than that of control (6.4 \pm 0.8 -fold), Dox@scrApt-hybr-TCL-SPION (5.2 \pm 0.6-fold), free Dox (5.0 \pm 0.4-fold) in vivo (xenograft mouse model). Therefore, the selective drug delivery efficacy (54\% higher than control) of Apt-hybr-TCL-SPION and active tumor-targeting ability of Dox@Apt-hybr-TCL-SPION made them suitable for PCa diagnosis and treatment. It also created a nanoplatform for therapeutic modalities (e.g., siRNAs, decoy ONTs containing an A 10 spacer and a 5'-(TCG) $7-3^{\prime}$ complementary sequence) in the era of cancer theranostic [123]. 
Table 3. Iron oxide nanoparticles-based treatment of prostate cancer.

\begin{tabular}{|c|c|c|c|c|c|c|c|c|c|}
\hline Treatment & $\begin{array}{l}\text { IONPs } \\
\text { Shape }\end{array}$ & Size & $\begin{array}{l}\text { Coating } \\
\text { Materials }\end{array}$ & $\begin{array}{l}\text { Drug/Radiation } \\
\text { Therapy Used }\end{array}$ & Cell Line & $\begin{array}{c}\text { In } \\
\text { Vivo }\end{array}$ & $\begin{array}{c}\text { Treatment } \\
\text { Period }\end{array}$ & Comments & Ref. \\
\hline PTT & $\begin{array}{l}\text { Nano } \\
\text { flower }\end{array}$ & $27 \pm 4 \mathrm{~nm}$ & NR & NR & PC-3 & NR & $30 \mathrm{~min}$ & $\begin{array}{c}\text { Induced } \\
\text { apoptosis and } \\
\text { necrosis for } \\
\text { PC-3 cell } \\
\text { destruction }\end{array}$ & [92] \\
\hline RT & Nanocapsule & $67 \mathrm{~nm}$ & PLGA & $\begin{array}{l}\text { 5-FU and x-ray } \\
\text { Radiation }\end{array}$ & DU145 & NR & $24 \mathrm{~h}$ & $\begin{array}{l}\text { An effective } \\
\text { drug delivery } \\
\text { vehicle for } \\
\text { 5-FU that can } \\
\text { penetrate the } \\
\text { cells }\end{array}$ & [93] \\
\hline \multirow{4}{*}{$\mathrm{CT}$} & Nanosphere & $\begin{array}{l}15.74 \pm \\
0.44 \mathrm{~nm}\end{array}$ & $\begin{array}{c}\text { PTX, } \\
\text { LHRH } \\
\text { peptide, } \\
\text { AE105 pep- } \\
\text { tide }\end{array}$ & PTX & $\begin{array}{c}\mathrm{RC} 77 \mathrm{~T} / \mathrm{E} \\
\text { and } \\
\mathrm{RC} 77 \mathrm{~N} / \mathrm{E}\end{array}$ & NR & NR & $\begin{array}{l}\text { Reduced the } \\
\text { viability of } \\
\text { PC-3 cells two } \\
\text { times, lowers } \\
\text { the toxicity of } \\
\text { PTX, enhances } \\
\text { pharmacoki- } \\
\text { netic efficiency } \\
\text { with better } \\
\text { patient } \\
\text { outcomes }\end{array}$ & [26] \\
\hline & Nanosphere & $8-10 \mathrm{~nm}$ & $\begin{array}{l}\text { DTX and } \\
\text { J591 }\end{array}$ & DTX & $\begin{array}{l}\text { C4-2 and } \\
\text { PC-3 }\end{array}$ & NR & NR & $\begin{array}{l}\text { Reduced the } \\
\text { levels of } \\
\text { MDR1 proteins } \\
\text { that help to } \\
\text { reduce } \\
\text { chemoresis- } \\
\text { tance of } \\
\text { drugs }\end{array}$ & [109] \\
\hline & NR & $\sim 100 \mathrm{~nm}$ & miRNA & DTX & $\begin{array}{l}\text { C4-2 and } \\
\text { PC-3 }\end{array}$ & NR & $8 \mathrm{~h}$ & $\begin{array}{l}\text { The number of } \\
\text { C4- } 2 \text { and } \\
\text { PC- } 3 \text { cell } \\
\text { colonies } \\
\text { declined by } \\
\text { approximately } \\
40 \% \text { compared } \\
\text { to the } \\
\text { non-treated } \\
\text { and DTX alone }\end{array}$ & [107] \\
\hline & core-shell & $\begin{array}{c}9.0 \pm \\
4.0 \mathrm{~nm}\end{array}$ & GSH-pDA & NR & PC-3 & NR & $24 \mathrm{~h}$ & $\begin{array}{l}\text { In response to } \\
\text { the } \mathrm{pH} \text { and } \\
\text { chemicals, the } \\
\text { drug is released } \\
\text { to the site of } \\
\text { action }\end{array}$ & [104] \\
\hline \multirow[t]{2}{*}{ HT } & Hexagonal & $\begin{array}{l}13.97 \pm \\
3.63 \mathrm{~nm}\end{array}$ & $\mathrm{Zn}$ and $\mathrm{Mn}$ & NR & $\begin{array}{c}\text { DU145 and } \\
\text { HEK-293 }\end{array}$ & $\begin{array}{l}\text { Mouse } \\
\text { Model } \\
\text { of } \\
\text { human } \\
\text { PCa }\end{array}$ & $24 \mathrm{~h}$ & $\begin{array}{l}\text { ZnMn-IONPs } \\
\text { killed more } \\
\text { than } 90 \% \text { of } \\
\text { PCa cells safely } \\
\text { without } \\
\text { noticeable } \\
\text { toxicity }\end{array}$ & [114] \\
\hline & $\begin{array}{l}\text { Irregular } \\
\text { shape }\end{array}$ & $\sim 12 \mathrm{~nm}$ & $\begin{array}{l}\text { ms-silica } \\
\text { shell }\end{array}$ & Silica & $\begin{array}{l}\text { LNCaP- } \\
\text { Pro5 }\end{array}$ & $\begin{array}{l}\text { Male } \\
\text { nude } \\
\text { mice }\end{array}$ & $24 \mathrm{~h}$ & $\begin{array}{c}\text { Efficient } \\
\text { heating } \\
\text { capability } \\
\text { made it } \\
\text { suitable for } \\
\text { PCa theranostic }\end{array}$ & [116] \\
\hline
\end{tabular}


Table 3. Cont

\begin{tabular}{|c|c|c|c|c|c|c|c|c|c|}
\hline Treatment & $\begin{array}{l}\text { IONPs } \\
\text { Shape }\end{array}$ & Size & $\begin{array}{l}\text { Coating } \\
\text { Materials }\end{array}$ & $\begin{array}{l}\text { Drug/Radiation } \\
\text { Therapy Used }\end{array}$ & Cell Line & $\begin{array}{c}\text { In } \\
\text { Vivo }\end{array}$ & $\begin{array}{l}\text { Treatment } \\
\text { Period }\end{array}$ & Comments & Ref. \\
\hline PTC-Based & $\begin{array}{l}\text { Regular } \\
\text { spherical }\end{array}$ & $\begin{array}{c}58.5 \pm \\
4 \mathrm{~nm}\end{array}$ & $\begin{array}{l}\text { mPEG-b- } \\
\text { PLGA }\end{array}$ & $\mathrm{Eu}$ & $\begin{array}{c}\text { DU-145, } \\
\text { LNCaP, } \\
\text { and } \\
\text { HUVECs }\end{array}$ & NR & $200 \mathrm{~h}$ & $\begin{array}{l}\text { Induced } \\
\text { apoptosis and } \\
\text { decreased the } \\
\text { rate of necrosis } \\
\text { at a lower dose }\end{array}$ & [94] \\
\hline \multirow{4}{*}{ Others } & Core-shell & $154.3 \mathrm{~nm}$ & $\begin{array}{l}\text { Wy5a } \\
\text { aptamer } \\
\text { (Apt) }\end{array}$ & DTX & PC-3 & $\begin{array}{l}\text { Mice } \\
\text { Model }\end{array}$ & 4 weeks & $\begin{array}{c}\text { Found } \\
\text { enhanced } \\
\text { efficacy of } \\
\text { CRPC } \\
\text { theranostic and } \\
\text { low toxicity to } \\
\text { the circulation } \\
\text { both in vivo } \\
\text { and in vitro }\end{array}$ & [120] \\
\hline & $\begin{array}{l}\text { Spherical } \\
\text { shape }\end{array}$ & $\begin{array}{l}146.9 \pm \\
8.6 \mathrm{~nm}\end{array}$ & scAbPSCA & DTX & PC-3 & NR & $\begin{array}{c}24,48, \text { and } \\
72 \mathrm{~h}\end{array}$ & $\begin{array}{l}\text { Showed an- } \\
\text { tiproliferative } \\
\text { activity against } \\
\text { PC3 as well as } \\
\text { MRI contrast } \\
\text { agent }\end{array}$ & [121] \\
\hline & NR & $\sim 5-\mathrm{nm}$ & Dextran & NR & HUVEC & $\begin{array}{l}\text { Xenografts } \\
\text { of } \\
\text { human } \\
\text { prostate } \\
\text { tissue }\end{array}$ & 30 days & $\begin{array}{l}\text { Bound to the } \\
\text { primary } \\
\text { xenografts of } \\
\text { human prostate } \\
\text { tissue on } \\
\text { ADT-damaged } \\
\text { human mi- } \\
\text { crovasculature } \\
\text { and prevention } \\
\text { of angiogenesis } \\
\text { to the PCa cells }\end{array}$ & [122] \\
\hline & NR & $\begin{array}{l}\sim 65 \pm \\
12 \mathrm{~nm}\end{array}$ & $\begin{array}{c}\text { PSMA } \\
\text { conjugated } \\
\text { TCL }\end{array}$ & DOX & LNCaP & $\begin{array}{l}\text { Male } \\
\text { nude } \\
\text { athymic } \\
\text { mice }\end{array}$ & $50 \mathrm{~h}$ & $\begin{array}{l}\text { Selectively } \\
\text { deliver } \\
\text { anticancer } \\
\text { drugs and } \\
\text { monitor the } \\
\text { therapeutic } \\
\text { response }\end{array}$ & [123] \\
\hline
\end{tabular}

PTT: Photothermal therapy; RT: Radiotherapy; CT: Chemotherapy; HT: Hyperthermia; PhC: Phytochemical; PSMA: prostate-specific membrane antigen; 5-FU: 5-Fluorouracil TCL-SPION: Thermally cross-linked superparamagnetic iron oxide nanoparticles; LNCaP: Prostate cancer cell lines; Aminosilane-APTES: N(2-aminoethyl)-3-aminopropyltriethoxysilane; BPH1: benign prostate hyperplastic epithelial cell; PC3: prostate cancer epithelial cell; mPEG: Polyethylene glycol; PLGA: Poly (lactic-co-glycolic) acid; DU-145: Human prostate cancer cell lines; Zn: Zinc; Mn: Manganese; Ms-silica: Mesoporus-Silica; Eu: Eupatorin; PTX: Paclitaxel; DTX: Docetaxel; FA: Folic Acid; IONP: Iron oxide nanoparticle; HUVEC: Human umbilical vein endothelial cells; ADT: Androgen deprivation therapy; CRPC: Castration-resistant prostate cancer; NR: Not reported.

\section{Toxicity}

IONPs and their surface-modified nanovectors have shown promise in cancer theranostic due to their target-specific binding, drug delivery efficiency, improved imaging, low cost, simplicity, affordability, convenience, telemedicine applications, high sensitivity to metastatic PCa, higher detection rate, and accuracy. However, the toxicity of IONPs is a controversial issue that depends on some factors e.g., size, surface chemistry, composition, and route of administration [93,124,125].

\subsection{In Vitro Toxicity}

Biocompatibility of IONPs is one of the major concern to be used it in PCa theranostic. Previously, many different cell lines (PCa cell lines and normal/healthy cell lines) were used by the researchers to find out its safety and killing efficiency of PCa cells $[26,60,61,81]$. Besides the highly enhanced capability of double-receptor-targeting IONPs (LHRH-AE105IONPs-PTX) to kill PC-3 cells (PCa cell line), it did not display noticeable toxicity to 
normal prostate epithelial cells $(\mathrm{RC} 77 \mathrm{~N} / \mathrm{E})$ at a concentration of $10 \mathrm{ng} / \mathrm{mL}$, even the concentration doubled to $20 \mathrm{ng} / \mathrm{mL}$ [26]. Similarly, Eupatorin loaded $\mathrm{Fe}_{3} \mathrm{O}_{4} @ \mathrm{mPEG}-\mathrm{b}-$ PLGA nanoparticles demonstrated a significant reduction of growth of cancer cell lines e.g., DU-145 and LNCaP cell through apoptosis but found to be safe almost safe (displayed negligible toxicity) against HUVECs as normal cells [94]. Furthermore, ZnMn-IONPs significantly killed more than 90\% PCa cells safely without noticeable toxicity to normal cells (non-malignant human embryonic kidney cells, HEK-293) [114]. However, Bonvin et al. found that both coated (FA-IONP) and uncoated IONP (at a concentration of $100 \mu \mathrm{g}$ $\mathrm{Fe} / \mathrm{mL}$ ) can be accumulated into the healthy prostate cells (RWPE-1) in a negligible amount than primary cancer cells (22Rv.1, +PSMA), early metastatic cells isolated from lymph nodes (LnCaP, +PSMA), and late metastatic cells isolated from bones (PC-3 cells) and found to be safe for biomedical applications [60]. Moreover, the composition of SPION also came as a deep concern. Chitosan (CS), and sarcosine oxidase (SOX) coated SPION were tested to be less toxic than non-modified SPION and found to be approximately seven times less toxic in S. cerevisiae and 5 times less hemolytic [81]. On the other hand, R11-PMNPs showed the death of $16 \%$ normal prostate epithelial cells (PZ-HPV-7) at the highest concentration (500 mg/mL) after $24 \mathrm{~h}$ of incubation. However, R11-PMNPs also did not exhibit toxic effects at $6 \mathrm{~h}$ of incubation period for both human dermal fibroblasts (HDFs) and normal prostate epithelial cells (PZ-HPV-7) [91].

\subsection{In Vivo Toxicity}

The interaction and biodistribution with various organs, normal cells, and systemic circulation were found to be so complicated. Among different factors size, surface chemistry, and route of administration became the major concern [93,124,125]. Feng et al. observed that $10 \mathrm{~nm}$-sized PEGylated IONPs were entered into the cell more frequently and showed a little cytotoxicity than $30 \mathrm{~nm}$ ones with high concentration [124]. Subcutaneous injection of FLUSPION ( $900 \mu \mathrm{mol} \mathrm{Fe} / \mathrm{kg}$ ) into BALB/c male nude mice showed accumulation into the liver, spleen, lung, and skin are the major consequences to use this nanoparticle in PCa theranostic [61]. On the contrary, direct injection of mesoporous silica-coated IONPs (ms-IONPs) into LNCaP PCa tumors in nude mice was found to be minimally toxic towards HDFn human skin fibroblasts [116]. Furthermore, subcutaneous administration of CQKHHNYLC conjugated SPION (concentration of $\mathrm{Fe}_{3} \mathrm{O}_{4}$ was $0.240 \mathrm{mg} / \mathrm{mL}$ ) showed to be accumulated into spleen and liver in LNCaP tumor-bearing mice [74]. Conversely, intravenous administration of USPION ( $2.6 \mathrm{mg}$ iron $/ \mathrm{kg}$ ) into 48 of PCa patients showed some adverse effects e.g., urticarial, hot flashes, hypertension, headache, swelling of neck and nose, and diarrhea in 11\% of patients [87]. Another study showed that thermo-responsive poly(N-isopropyl acrylamide-acrylamide-allylamine)-coated magnetic nanoparticles (PMNPs) were accumulated in a higher concentration than conjugated PMNPs (R-11 PMNPs) in the spleen, liver, prostate, and kidney after intravenous injection [91].

\section{Conclusions and Future Prospective}

The indolent phase of PCa cells, drug resistance, and metastatic condition make them difficult for early diagnosis and proper treatment. IONPs have shown promises in the early diagnosis and treatment, especially by acting as MRI contrast agent and targeted drug delivery system. Surface tuned IONPs displayed promise in PCa diagnosis with accuracy, reliability, and reproducibility in cell line model to clinical samples. Additionally, IONPs can effectively be used as a carrier to deliver photothermal agents, chemotherapeutic drugs, bioactive phytochemicals, and other therapeutic polymers or ligands. The surface-modified IONPs improved the therapeutic potential of resistant conventional drugs, reduced cytotoxicity, and therefore improved the therapeutic window against PCa cells. Recently, it has been reported that Ferumoxytol (FTX), an FDA-approved IONP, conjugated heptamethine (HPT) carbocyanine visualized PCa tumor margin via near-infrared fluorescence imaging. The IONP-based complex also acts as an anticancer drug carrier. Therefore, this theranostic FTX-HPT nanocomplex could be used in image guide PCa surgery [126]. IONPs 
have demonstrated antiproliferative activity both in the in vitro and in vivo models with minimal side effects. However, fewer preclinical studies have been conducted so far to evaluate the theranostic potential of IONPs. Furthermore, some research groups confirmed the cytotoxic activity, systemic toxicity, and long-term accumulation into vital organs such as the liver, spleen, lung, and skin. As the biocompatibility of IONPs is still a controversial issue [28,127], extensive preclinical trials should be performed to assure safety prior to clinical application as a PCa theranostic agent.

Author Contributions: Conceptualization: M.S.S.; Manuscript writing: M.A.R., M.S.S.; Figure drawing: M.S.H. and M.A.R.; Manuscript corrections: M.S.S., M.S.H., M.S.N. and M.H.B.; Manuscript revision and approval: M.S.S. and S.P. All authors have read and agreed to the published version of the manuscript.

Funding: This article did not receive any external funding.

Institutional Review Board Statement: Not applicable.

Informed Consent Statement: Not applicable.

Data Availability Statement: Data reported in the Table 1 are available at cBioportal database (https: / www.cbioportal.org/) (accessed on 15 March 2021).

Conflicts of Interest: The authors declare no conflict of interest.

\section{References}

1. Gandhi, J.; Afridi, A.; Vatsia, S.; Joshi, G.; Joshi, G.; Kaplan, S.A.; Smith, N.L.; Khan, S.A. The molecular biology of prostate cancer: Current understanding and clinical implications. Prostate Cancer Prostatic Dis. 2018, 21, 22-36. [CrossRef] [PubMed]

2. Rana, Z.; Tyndall, J.D.; Hanif, M.; Hartinger, C.G.; Rosengren, R.J.J.P. Cytostatic Action of Novel Histone Deacetylase Inhibitors in Androgen Receptor-Null Prostate Cancer Cells. Pharm 2021, 14, 103. [CrossRef]

3. Printz, C. Prostate cancer mortality projections reach a new high: With prostate cancer deaths projected to rise to their highest level in 20 years, some experts worry that changes to screening guidelines made in 2012 could be a factor. Cancer 2020, 126, 3893-3894. [CrossRef]

4. Culp, M.B.; Soerjomataram, I.; Efstathiou, J.A.; Bray, F.; Jemal, A. Recent Global Patterns in Prostate Cancer Incidence and Mortality Rates. Eur. Urol. 2020, 77, 38-52. [CrossRef] [PubMed]

5. Reda, I.; Khalil, A.; Elmogy, M.; Abou El-Fetouh, A.; Shalaby, A.; Abou El-Ghar, M.; Elmaghraby, A.; Ghazal, M.; El-Baz, A. Deep Learning Role in Early Diagnosis of Prostate Cancer. Technol. Cancer Res. Treat. 2018, 17. [CrossRef] [PubMed]

6. Gobbo, O.L.; Sjaastad, K.; Radomski, M.W.; Volkov, Y.; Prina-Mello, A. Magnetic Nanoparticles in Cancer Theranostics. Theranostics 2015, 5, 1249-1263. [CrossRef]

7. Kohaar, I.; Petrovics, G.; Srivastava, S. A Rich Array of Prostate Cancer Molecular Biomarkers: Opportunities and Challenges. Int. J. Mol. Sci. 2019, 20, 1813. [CrossRef]

8. Oh, S.W.; Cheon, G.J. Prostate-Specific Membrane Antigen PET Imaging in Prostate Cancer: Opportunities and Challenges. Korean J. Radiol. 2018, 19, 819-831. [CrossRef]

9. Pan, L.H.; Kuo, S.H.; Lin, T.Y.; Lin, C.W.; Fang, P.Y.; Yang, H.W. An electrochemical biosensor to simultaneously detect VEGF and PSA for early prostate cancer diagnosis based on graphene oxide/ssDNA/PLLA nanoparticles. Biosens. Bioelectron. 2017, 89, 598-605. [CrossRef]

10. Ahdoot, M.; Wilbur, A.R.; Reese, S.E.; Lebastchi, A.H.; Mehralivand, S.; Gomella, P.T.; Bloom, J.; Gurram, S.; Siddiqui, M.; Pinsky, P. MRI-targeted, systematic, and combined biopsy for prostate cancer diagnosis. N. Engl. J. Med. 2020, 382, 917-928. [CrossRef]

11. Sushentsev, N.; Kaggie, J.D.; Buonincontri, G.; Schulte, R.F.; Graves, M.J.; Gnanapragasam, V.J.; Barrett, T. The effect of gadoliniumbased contrast agent administration on magnetic resonance fingerprinting-based $\mathrm{T}(1)$ relaxometry in patients with prostate cancer. Sci. Rep. 2020, 10, 20475. [CrossRef]

12. Helfand, B.T.; Glaser, A.P.; Rimar, K.; Zargaroff, S.; Hedges, J.; McGuire, B.B.; Catalona, W.J.; McVary, K.T. Prostate cancer diagnosis is associated with an increased risk of erectile dysfunction after prostate biopsy. BJU Int. 2013, 111, 38-43. [CrossRef] [PubMed]

13. Shakil, M.S.; Hasan, M.A.; Uddin, M.F.; Islam, A.; Nahar, A.; Das, H.; Khan, M.N.I.; Dey, B.P.; Rokeya, B.; Hoque, S.M.J.A.A.B.M. In Vivo Toxicity Studies of Chitosan-Coated Cobalt Ferrite Nanocomplex for Its Application as MRI Contrast Dye. ACS Appl. Bio Mater. 2020, 3, 7952-7964. [CrossRef]

14. Soares, S.C.M.; de Camargo Cancela, M.; Migowski, A.; de Souza, D.L.B. Digital rectal examination and its associated factors in the early detection of prostate cancer: A cross-sectional population-based study. BMC Public Health 2019, 19, 1573. [CrossRef] [PubMed] 
15. Naji, L.; Randhawa, H.; Sohani, Z.; Dennis, B.; Lautenbach, D.; Kavanagh, O.; Bawor, M.; Banfield, L.; Profetto, J. Digital Rectal Examination for Prostate Cancer Screening in Primary Care: A Systematic Review and Meta-Analysis. Ann. Fam. Med. 2018, 16, 149-154. [CrossRef]

16. Tosoian, J.J.; Druskin, S.C.; Andreas, D.; Mullane, P.; Chappidi, M.; Joo, S.; Ghabili, K.; Mamawala, M.; Agostino, J.; Carter, H.B.; et al. Prostate Health Index density improves detection of clinically significant prostate cancer. BJU Int. 2017, 120, 793-798. [CrossRef]

17. Wilt, T.J.; Ahmed, H.U. Prostate cancer screening and the management of clinically localized disease. BMJ Clin. Res. Ed. 2013, 346, f325. [CrossRef] [PubMed]

18. Resnick, M.J.; Koyama, T.; Fan, K.H.; Albertsen, P.C.; Goodman, M.; Hamilton, A.S.; Hoffman, R.M.; Potosky, A.L.; Stanford, J.L.; Stroup, A.M.; et al. Long-term functional outcomes after treatment for localized prostate cancer. N. Engl. J. Med. 2013, 368, 436-445. [CrossRef]

19. Perlmutter, M.A.; Lepor, H. Androgen deprivation therapy in the treatment of advanced prostate cancer. Rev. Urol. 2007, 9, S3.

20. Chaussy, C.G.; Thüroff, S. High-Intensity Focused Ultrasound for the Treatment of Prostate Cancer: A Review. J. Endourol. 2017, 31, S30-S37. [CrossRef]

21. Chennupati, S.K.; Pelizzari, C.A.; Kunnavakkam, R.; Liauw, S.L. Late toxicity and quality of life after definitive treatment of prostate cancer: Redefining optimal rectal sparing constraints for intensity-modulated radiation therapy. Cancer Med. 2014, 3, 954-961. [CrossRef] [PubMed]

22. Ramachandra Kurup Sasikala, A.; Thomas, R.G.; Unnithan, A.R.; Saravanakumar, B.; Jeong, Y.Y.; Park, C.H.; Kim, C.S. Multifunctional Nanocarpets for Cancer Theranostics: Remotely Controlled Graphene Nanoheaters for Thermo-Chemosensitisation and Magnetic Resonance Imaging. Sci. Rep. 2016, 6, 20543. [CrossRef]

23. Dadfar, S.M.; Roemhild, K.; Drude, N.I.; von Stillfried, S.; Knüchel, R.; Kiessling, F.; Lammers, T. Iron oxide nanoparticles: Diagnostic, therapeutic and theranostic applications. Adv. Drug Deliv. Rev. 2019, 138, 302-325. [CrossRef]

24. $\mathrm{Wu}, \mathrm{W}$.; He, Q.; Jiang, C. Magnetic iron oxide nanoparticles: Synthesis and surface functionalization strategies. Nanoscale Res. Lett. 2008, 3, 397-415. [CrossRef]

25. Singh, A.; Sahoo, S.K. Magnetic nanoparticles: A novel platform for cancer theranostics. Drug Discov. Today 2014, 19, 474-481. [CrossRef] [PubMed]

26. Ahmed, M.S.U.; Salam, A.B.; Yates, C.; Willian, K.; Jaynes, J.; Turner, T.; Abdalla, M.O. Double-receptor-targeting multifunctional iron oxide nanoparticles drug delivery system for the treatment and imaging of prostate cancer. Int. J. Nanomed. 2017, 12, 6973-6984. [CrossRef] [PubMed]

27. Sterenczak, K.A.; Meier, M.; Glage, S.; Meyer, M.; Willenbrock, S.; Wefstaedt, P.; Dorsch, M.; Bullerdiek, J.; Murua Escobar, H.; Hedrich, H.; et al. Longitudinal MRI contrast enhanced monitoring of early tumour development with manganese chloride $(\mathrm{MnCl})$ and superparamagnetic iron oxide nanoparticles (SPIOs) in a CT1258 based in vivo model of prostate cancer. BMC Cancer 2012, 12, 284. [CrossRef] [PubMed]

28. Shakil, M.S.; Hasan, M.A.; Sarker, S.R. Iron Oxide Nanoparticles for Breast Cancer Theranostics. Curr. Drug Metab. 2019, 20, 446-456. [CrossRef]

29. Inamura, K. Prostatic cancers: Understanding their molecular pathology and the 2016 WHO classification. Oncotarget 2018, 9 , 14723-14737. [CrossRef]

30. Mazaris, E.; Tsiotras, A.J.N.-u.m. Molecular pathways in prostate cancer. Nephro-urol. Mon. 2013, 5, 792. [CrossRef]

31. Cerami, E.; Gao, J.; Dogrusoz, U.; Gross, B.E.; Sumer, S.O.; Aksoy, B.A.; Jacobsen, A.; Byrne, C.J.; Heuer, M.L.; Larsson, E.; et al. The cBio cancer genomics portal: An open platform for exploring multidimensional cancer genomics data. Cancer Discov. 2012, 2, 401-404. [CrossRef] [PubMed]

32. Gao, J.; Aksoy, B.A.; Dogrusoz, U.; Dresdner, G.; Gross, B.; Sumer, S.O.; Sun, Y.; Jacobsen, A.; Sinha, R.; Larsson, E.; et al. Integrative analysis of complex cancer genomics and clinical profiles using the cBioPortal. Sci. Signal. 2013, 6, pl1. [CrossRef] [PubMed]

33. Gerhauser, C.; Favero, F.; Risch, T.; Simon, R.; Feuerbach, L.; Assenov, Y.; Heckmann, D.; Sidiropoulos, N.; Waszak, S.M.; Hübschmann, D.; et al. Molecular Evolution of Early-Onset Prostate Cancer Identifies Molecular Risk Markers and Clinical Trajectories. Cancer Cell 2018, 34, 996-1011.e1018. [CrossRef] [PubMed]

34. Granlund, K.L.; Tee, S.S.; Vargas, H.A.; Lyashchenko, S.K.; Reznik, E.; Fine, S.; Laudone, V.; Eastham, J.A.; Touijer, K.A.; Reuter, V.E.; et al. Hyperpolarized MRI of Human Prostate Cancer Reveals Increased Lactate with Tumor Grade Driven by Monocarboxylate Transporter 1. Cell Metab. 2020, 31, 105-114.e103. [CrossRef]

35. Grasso, C.S.; Wu, Y.M.; Robinson, D.R.; Cao, X.; Dhanasekaran, S.M.; Khan, A.P.; Quist, M.J.; Jing, X.; Lonigro, R.J.; Brenner, J.C.; et al. The mutational landscape of lethal castration-resistant prostate cancer. Nature 2012, 487, 239-243. [CrossRef]

36. Abida, W.; Cyrta, J.; Heller, G.; Prandi, D.; Armenia, J.; Coleman, I.; Cieslik, M.; Benelli, M.; Robinson, D.; Van Allen, E.M.; et al. Genomic correlates of clinical outcome in advanced prostate cancer. Proc. Natl. Acad. Sci. USA 2019, 116, 11428-11436. [CrossRef]

37. Robinson, D.; Van Allen, E.M.; Wu, Y.M.; Schultz, N.; Lonigro, R.J.; Mosquera, J.M.; Montgomery, B.; Taplin, M.E.; Pritchard, C.C.; Attard, G.; et al. Integrative clinical genomics of advanced prostate cancer. Cell 2015, 161, 1215-1228. [CrossRef] [PubMed]

38. Stopsack, K.H.; Nandakumar, S.; Wibmer, A.G.; Haywood, S.; Weg, E.S.; Barnett, E.S.; Kim, C.J.; Carbone, E.A.; Vasselman, S.E.; Nguyen, B.; et al. Oncogenic Genomic Alterations, Clinical Phenotypes, and Outcomes in Metastatic Castration-Sensitive Prostate Cancer. Clin. Cancer Res. Off. J. Am. Assoc. Cancer Res. 2020, 26, 3230-3238. [CrossRef] [PubMed] 
39. Beltran, H.; Prandi, D.; Mosquera, J.M.; Benelli, M.; Puca, L.; Cyrta, J.; Marotz, C.; Giannopoulou, E.; Chakravarthi, B.V.; Varambally, S.; et al. Divergent clonal evolution of castration-resistant neuroendocrine prostate cancer. Nat. Med. 2016, 22, 298-305. [CrossRef]

40. Kumar, A.; Coleman, I.; Morrissey, C.; Zhang, X.; True, L.D.; Gulati, R.; Etzioni, R.; Bolouri, H.; Montgomery, B.; White, T.; et al. Substantial interindividual and limited intraindividual genomic diversity among tumors from men with metastatic prostate cancer. Nat. Med. 2016, 22, 369-378. [CrossRef]

41. Taylor, B.S.; Schultz, N.; Hieronymus, H.; Gopalan, A.; Xiao, Y.; Carver, B.S.; Arora, V.K.; Kaushik, P.; Cerami, E.; Reva, B.; et al. Integrative genomic profiling of human prostate cancer. Cancer Cell 2010, 18, 11-22. [CrossRef]

42. Hieronymus, H.; Schultz, N.; Gopalan, A.; Carver, B.S.; Chang, M.T.; Xiao, Y.; Heguy, A.; Huberman, K.; Bernstein, M.; Assel, M.; et al. Copy number alteration burden predicts prostate cancer relapse. Proc. Natl. Acad. Sci. USA 2014, 111, 1113911144. [CrossRef] [PubMed]

43. Armenia, J.; Wankowicz, S.A.M.; Liu, D.; Gao, J.; Kundra, R.; Reznik, E.; Chatila, W.K.; Chakravarty, D.; Han, G.C.; Coleman, I.; et al. The long tail of oncogenic drivers in prostate cancer. Nat. Genet. 2018, 50, 645-651. [CrossRef] [PubMed]

44. Hoadley, K.A.; Yau, C.; Hinoue, T.; Wolf, D.M.; Lazar, A.J.; Drill, E.; Shen, R.; Taylor, A.M.; Cherniack, A.D.; Thorsson, V.; et al. Cell-of-Origin Patterns Dominate the Molecular Classification of 10,000 Tumors from 33 Types of Cancer. Cell 2018, 173, 291-304.e296. [CrossRef] [PubMed]

45. Gao, D.; Vela, I.; Sboner, A.; Iaquinta, P.J.; Karthaus, W.R.; Gopalan, A.; Dowling, C.; Wanjala, J.N.; Undvall, E.A.; Arora, V.K.; et al. Organoid cultures derived from patients with advanced prostate cancer. Cell 2014, 159, 176-187. [CrossRef] [PubMed]

46. Abida, W.; Armenia, J.; Gopalan, A.; Brennan, R.; Walsh, M.; Barron, D.; Danila, D.; Rathkopf, D.; Morris, M.; Slovin, S.; et al. Prospective Genomic Profiling of Prostate Cancer Across Disease States Reveals Germline and Somatic Alterations That May Affect Clinical Decision Making. JCO Precis. Oncol. 2017, 1, 1-16. [CrossRef]

47. cBioPortal for Cancer Genomics. The Metastatic Prostate Cancer Project (Provisional, November 2019). Available online: https:/ / bit.ly/32YuZ6J (accessed on 15 March 2021).

48. cBioPortal for Cancer Genomics. Prostate Cancer. Available online: https:// bit.ly/3cRgaqS (accessed on 15 March 2021).

49. Shoag, J.; Barbieri, C.E. Clinical variability and molecular heterogeneity in prostate cancer. Asian J. Androl. 2016, 18, 543-548. [CrossRef]

50. Yadav, S.S.; Stockert, J.A.; Hackert, V.; Yadav, K.K.; Tewari, A.K. Intratumor heterogeneity in prostate cancer. Urol. Oncol. 2018, 36, 349-360. [CrossRef]

51. Weissleder, R. Molecular imaging in cancer. Science 2006, 312, 1168-1171. [CrossRef] [PubMed]

52. Ansari, M.O.; Ahmad, M.F.; Shadab, G.; Shadab, G.G.H.A.; Siddique, H.R. Superparamagnetic iron oxide nanoparticles based cancer theranostics: A double edge sword to fight against cancer. J. Drug Deliv. Sci. Technol. 2018, 45, 177-183. [CrossRef]

53. Zhu, S.; Wang, Q.; Jiang, J.; Luo, Y.; Sun, Z. A conjugate of methotrexate and an analog of luteinizing hormone releasing hormone shows increased efficacy against prostate cancer. Sci. Rep. 2016, 6, 33894. [CrossRef]

54. Popovics, P.; Schally, A.V.; Szalontay, L.; Block, N.L.; Rick, F.G. Targeted cytotoxic analog of luteinizing hormone-releasing hormone (LHRH), AEZS-108 (AN-152), inhibits the growth of DU-145 human castration-resistant prostate cancer in vivo and in vitro through elevating p21 and ROS levels. Oncotarget 2014, 5, 4567-4578. [CrossRef] [PubMed]

55. Patel, O.; Shulkes, A.; Baldwin, G.S. Gastrin-releasing peptide and cancer. Biochim. et Biophys. Acta 2006, 1766, 23-41. [CrossRef] [PubMed]

56. Martin, A.L.; Hickey, J.L.; Ablack, A.L.; Lewis, J.D.; Luyt, L.G.; Gillies, E.R. Synthesis of bombesin-functionalized iron oxide nanoparticles and their specific uptake in prostate cancer cells. J. Nanoparticle Res. Interdiscip. Forum Nanoscale Sci. Technol. 2009, 12, 1599-1608. [CrossRef] [PubMed]

57. Hartmann, L.C.; Keeney, G.L.; Lingle, W.L.; Christianson, T.J.; Varghese, B.; Hillman, D.; Oberg, A.L.; Low, P.S. Folate receptor overexpression is associated with poor outcome in breast cancer. Int. J. Cancer 2007, 121, 938-942. [CrossRef]

58. Lee, R.J.; Low, P.S. Folate-mediated tumor cell targeting of liposome-entrapped doxorubicin in vitro. Biochim. Et Biophys. Acta 1995, 1233, 134-144. [CrossRef]

59. Zhang, Y.; Liu, J.M.; Yan, X.P. Self-assembly of folate onto polyethyleneimine-coated CdS/ZnS quantum dots for targeted turn-on fluorescence imaging of folate receptor overexpressed cancer cells. Anal. Chem. 2013, 85, 228-234. [CrossRef]

60. Bonvin, D.; Bastiaansen, J.A.M.; Stuber, M.; Hofmann, H.; Mionić Ebersold, M. Folic acid on iron oxide nanoparticles: Platform with high potential for simultaneous targeting, MRI detection and hyperthermia treatment of lymph node metastases of prostate cancer. Dalton Trans. 2017, 46, 12692-12704. [CrossRef]

61. Jayapaul, J.; Arns, S.; Bunker, M.; Weiler, M.; Rutherford, S.; Comba, P.; Kiessling, F. In vivo evaluation of riboflavin receptor targeted fluorescent USPIO in mice with prostate cancer xenografts. Nano Res. 2016, 9, 1319-1333. [CrossRef] [PubMed]

62. Saeki, N.; Gu, J.; Yoshida, T.; Wu, X. Prostate stem cell antigen: A Jekyll and Hyde molecule? Clin. Cancer Res. Off. J. Am. Assoc. Cancer Res. 2010, 16, 3533-3538. [CrossRef]

63. Patra, P.; Bhattacharya, M.; Sharma, A.R.; Ghosh, P.; Sharma, G.; Patra, B.C.; Mallick, B.; Lee, S.S.; Chakraborty, C. Identification and Design of a Next-Generation Multi Epitopes Bases Peptide Vaccine Candidate Against Prostate Cancer: An In Silico Approach. Cell Biochem. Biophys. 2020. [CrossRef] [PubMed] 
64. Shahrabi Farahani, M.; Mohsenzadegan, M.; Taeb, J.; Farajollahi, M.M. In-vitro prostate cancer biomarker detection by directed conjugation of anti-PSCA antibody to super paramagnetic iron oxide nanoparticless. Med. J. Islamic Repub. Iran 2019, 33, 16. [CrossRef]

65. Reiter, R.E.; Sato, I.; Thomas, G.; Qian, J.; Gu, Z.; Watabe, T.; Loda, M.; Jenkins, R.B. Coamplification of prostate stem cell antigen (PSCA) and MYC in locally advanced prostate cancer. Geneschromosomes Cancer 2000, 27, 95-103. [CrossRef]

66. Meller, B.; Bremmer, F.; Sahlmann, C.O.; Hijazi, S.; Bouter, C.; Trojan, L.; Meller, J.; Thelen, P. Alterations in androgen deprivation enhanced prostate-specific membrane antigen (PSMA) expression in prostate cancer cells as a target for diagnostics and therapy. EJNMMI Res. 2015, 5, 66. [CrossRef]

67. Perera, M.; Papa, N.; Christidis, D.; Wetherell, D.; Hofman, M.S.; Murphy, D.G.; Bolton, D.; Lawrentschuk, N.J.E.u. Sensitivity, specificity, and predictors of positive 68Ga-prostate-specific membrane antigen positron emission tomography in advanced prostate cancer: A systematic review and meta-analysis. J. Drug Deliv. Sci. Technol. 2016, 70, 926-937. [CrossRef]

68. Holland, J.P.; Divilov, V.; Bander, N.H.; Smith-Jones, P.M.; Larson, S.M.; Lewis, J.S. 89Zr-DFO-J591 for immunoPET of prostatespecific membrane antigen expression in vivo. J. Nucl. Med. Off. Publ. Soc. Nucl. Med. 2010, 51, 1293-1300. [CrossRef]

69. Bander, N.H.; Milowsky, M.I.; Nanus, D.M.; Kostakoglu, L.; Vallabhajosula, S.; Goldsmith, S.J. Phase I trial of 177lutetium-labeled J591, a monoclonal antibody to prostate-specific membrane antigen, in patients with androgen-independent prostate cancer. $J$. Clin. Oncol. Off. J. Am. Soc. Clin. Oncol. 2005, 23, 4591-4601. [CrossRef]

70. Bander, N.H.; Trabulsi, E.J.; Kostakoglu, L.; Yao, D.; Vallabhajosula, S.; Smith-Jones, P.; Joyce, M.A.; Milowsky, M.; Nanus, D.M.; Goldsmith, S.J. Targeting metastatic prostate cancer with radiolabeled monoclonal antibody J591 to the extracellular domain of prostate specific membrane antigen. J. Urol. 2003, 170, 1717-1721. [CrossRef]

71. Bates, D.; Abraham, S.; Campbell, M.; Zehbe, I.; Curiel, L. Development and characterization of an antibody-labeled superparamagnetic iron oxide contrast agent targeting prostate cancer cells for magnetic resonance imaging. PLoS ONE 2014, 9, e97220. [CrossRef]

72. Abdolahi, M.; Shahbazi-Gahrouei, D.; Laurent, S.; Sermeus, C.; Firozian, F.; Allen, B.J.; Boutry, S.; Muller, R.N. Synthesis and in vitro evaluation of MR molecular imaging probes using J591 mAb-conjugated SPIONs for specific detection of prostate cancer. Contrast Media Mol. Imaging 2013, 8, 175-184. [CrossRef]

73. Tse, B.W.; Cowin, G.J.; Soekmadji, C.; Jovanovic, L.; Vasireddy, R.S.; Ling, M.T.; Khatri, A.; Liu, T.; Thierry, B.; Russell, P.J. PSMA-targeting iron oxide magnetic nanoparticles enhance MRI of preclinical prostate cancer. Nanomed. Lond. Engl. 2015, 10, 375-386. [CrossRef]

74. Zhu, Y.; Sun, Y.; Chen, Y.; Liu, W.; Jiang, J.; Guan, W.; Zhang, Z.; Duan, Y. In Vivo Molecular MRI Imaging of Prostate Cancer by Targeting PSMA with Polypeptide-Labeled Superparamagnetic Iron Oxide Nanoparticles. Int. J. Mol. Sci. 2015, 16, 9573-9587. [CrossRef]

75. Zhou, J.; Huang, L.; Wang, W.; Pang, J.; Zou, Y.; Shuai, X.; Gao, X.J.C.S.B. Prostate cancer targeted MRI nanoprobe based on superparamagnetic iron oxide and copolymer of poly (ethylene glycol) and polyethyleneimin. Chin. Sci. Bull. 2009, 54, 3137-3146. [CrossRef]

76. Farshchi, F.; Hasanzadeh, M.; Mokhtarzadeh, A. A novel electroconductive interface based on Fe3O4 magnetic nanoparticle and cysteamine functionalized AuNPs: Preparation and application as signal amplification element to minoring of antigen-antibody immunocomplex and biosensing of prostate cancer. J. Mol. Recognit. 2020, 33, e2825. [CrossRef]

77. Zhang, W.; Li, K.; Guo, J.; Ma, T.; Wang, D.; Shi, S.; Gopinath, S.C.B.; Gu, D. Sensitive identification of prostate-specific antigen by iron oxide nanoparticle antibody conjugates on the gap-finger electrode surface. Biotechnol. Appl. Biochem. 2020. [CrossRef] [PubMed]

78. Cernei, N.; Heger, Z.; Gumulec, J.; Zitka, O.; Masarik, M.; Babula, P.; Eckschlager, T.; Stiborova, M.; Kizek, R.; Adam, V. Sarcosine as a potential prostate cancer biomarker-A review. Int. J. Mol. Sci. 2013, 14, 13893-13908. [CrossRef] [PubMed]

79. de Andrade, R.B.; Gemelli, T.; Rojas, D.B.; Dutra-Filho, C.S.; Wannmacher, C.M. Chemically induced acute model of sarcosinemia in wistar rats. Metab. Brain Dis. 2016, 31, 363-368. [CrossRef]

80. Khan, A.P.; Rajendiran, T.M.; Ateeq, B.; Asangani, I.A.; Athanikar, J.N.; Yocum, A.K.; Mehra, R.; Siddiqui, J.; Palapattu, G.; Wei, J.T.; et al. The role of sarcosine metabolism in prostate cancer progression. Neoplasia 2013, 15, 491-501. [CrossRef]

81. Uhlirova, D.; Stankova, M.; Docekalova, M.; Hosnedlova, B.; Kepinska, M.; Ruttkay-Nedecky, B.; Ruzicka, J.; Fernandez, C.; Milnerowicz, H.; Kizek, R. A Rapid Method for the Detection of Sarcosine Using SPIONs/Au/CS/SOX/NPs for Prostate Cancer Sensing. Int. J. Mol. Sci. 2018, 19, 3722. [CrossRef]

82. Garcia-Uribe, A.; Erpelding, T.N.; Krumholz, A.; Ke, H.; Maslov, K.; Appleton, C.; Margenthaler, J.A.; Wang, L.V. Dual-Modality Photoacoustic and Ultrasound Imaging System for Noninvasive Sentinel Lymph Node Detection in Patients with Breast Cancer. Sci. Rep. 2015, 5, 15748. [CrossRef]

83. How, J.; Lau, S.; Press, J.; Ferenczy, A.; Pelmus, M.; Stern, J.; Probst, S.; Brin, S.; Drummond, N.; Gotlieb, W. Accuracy of sentinel lymph node detection following intra-operative cervical injection for endometrial cancer: A prospective study. Gynecol. Oncol. 2012, 127, 332-337. [CrossRef]

84. Winter, A.; Woenkhaus, J.; Wawroschek, F. A novel method for intraoperative sentinel lymph node detection in prostate cancer patients using superparamagnetic iron oxide nanoparticles and a handheld magnetometer: The initial clinical experience. Ann. Surg. Oncol. 2014, 21, 4390-4396. [CrossRef] 
85. Winter, A.; Kowald, T.; Paulo, T.S.; Goos, P.; Engels, S.; Gerullis, H.; Schiffmann, J.; Chavan, A.; Wawroschek, F. Magnetic resonance sentinel lymph node imaging and magnetometer-guided intraoperative detection in prostate cancer using superparamagnetic iron oxide nanoparticles. Int. J. Nanomed. 2018, 13, 6689-6698. [CrossRef]

86. Li, C.S.; Harisinghani, M.G.; Lin, W.C.; Braschi, M.; Hahn, P.F.; Mueller, P.R. Enhancement characteristics of ultrasmall superparamagnetic iron oxide particle within the prostate gland in patients with primary prostate cancer. J. Comput. Assist. Tomogr. 2008, 32, 523-528. [CrossRef]

87. Triantafyllou, M.; Studer, U.E.; Birkhäuser, F.D.; Fleischmann, A.; Bains, L.J.; Petralia, G.; Christe, A.; Froehlich, J.M.; Thoeny, H.C. Ultrasmall superparamagnetic particles of iron oxide allow for the detection of metastases in normal sized pelvic lymph nodes of patients with bladder and/or prostate cancer. Eur. J. Cancer 2013, 49, 616-624. [CrossRef]

88. Li, Y.R.; Dattoli, M.J.; Barentsz, J.; Roach, M. Radiotherapy (RT) guided by ultra-small superparamagnetic iron oxide (USPIO)contrast MRI staging for patients with advanced or recurrent prostate cancer. J. Clin. Oncol. 2020, 38, 218. [CrossRef]

89. Jiang, J.; Chen, Y.; Zhu, Y.; Yao, X.; Qi, J. Efficient in vitro labeling of human prostate cancer cells with superparamagnetic iron oxide nanoparticles. Cancer Biother. Radiopharm. 2011, 26, 461-467. [CrossRef]

90. Ding, C.; Wu, K.; Wang, W.; Guan, Z.; Wang, L.; Wang, X.; Wang, R.; Liu, L.; Fan, J. Synthesis of a cell penetrating peptide modified superparamagnetic iron oxide and MRI detection of bladder cancer. Oncotarget 2017, 8, 4718-4729. [CrossRef] [PubMed]

91. Wadajkar, A.S.; Menon, J.U.; Tsai, Y.S.; Gore, C.; Dobin, T.; Gandee, L.; Kangasniemi, K.; Takahashi, M.; Manandhar, B.; Ahn, J.M.; et al. Prostate cancer-specific thermo-responsive polymer-coated iron oxide nanoparticles. Biomaterials 2013, 34, 3618-3625. [CrossRef] [PubMed]

92. Cabana, S.; Curcio, A.; Michel, A.; Wilhelm, C.; Abou-Hassan, A. Iron Oxide Mediated Photothermal Therapy in the Second Biological Window: A Comparative Study between Magnetite/Maghemite Nanospheres and Nanoflowers. Nanomaterials 2020, 10, 1548. [CrossRef] [PubMed]

93. Hajikarimi, Z.; Khoei, S.; Khoee, S.; Mahdavi, S.R. Evaluation of the cytotoxic effects of PLGA coated iron oxide nanoparticles as a carrier of 5-fluorouracil and mega-voltage X-ray radiation in DU145 prostate cancer cell line. IEEE Trans. Nanobiosci. 2014, 13, 403-408. [CrossRef]

94. Tousi, M.S.; Sepehri, H.; Khoee, S.; Farimani, M.; Delphi, L.; Mansourizadeh, F.J.J.o.P.A. Evaluation of apoptotic effects of mPEG-b-PLGA coated iron oxide nanoparticles as a eupatorin carrier on DU-145 and LNcaP human prostate cancer cell lines. J. Pharm. Anal. 2020, 11, 108-121. [CrossRef]

95. Nomura, S.; Morimoto, Y.; Tsujimoto, H.; Arake, M.; Harada, M.; Saitoh, D.; Hara, I.; Ozeki, E.; Satoh, A.; Takayama, E.; et al. Highly reliable, targeted photothermal cancer therapy combined with thermal dosimetry using a near-infrared absorbent. Sci. Rep. 2020, 10, 9765. [CrossRef]

96. Stupp, R.; Mason, W.P.; van den Bent, M.J.; Weller, M.; Fisher, B.; Taphoorn, M.J.; Belanger, K.; Brandes, A.A.; Marosi, C.; Bogdahn, U.; et al. Radiotherapy plus concomitant and adjuvant temozolomide for glioblastoma. N. Engl. J. Med. 2005, 352, 987-996. [CrossRef] [PubMed]

97. Siddiqui, Z.A.; Krauss, D.J. Adjuvant androgen deprivation therapy for prostate cancer treated with radiation therapy. Transl. Androl. Urol. 2018, 7, 378-389. [CrossRef] [PubMed]

98. Shipley, W.U.; Seiferheld, W.; Lukka, H.R.; Major, P.P.; Heney, N.M.; Grignon, D.J.; Sartor, O.; Patel, M.P.; Bahary, J.P.; Zietman, A.L.; et al. Radiation with or without Antiandrogen Therapy in Recurrent Prostate Cancer. N. Engl. J. Med. 2017, 376, 417-428. [CrossRef]

99. Zhang, N.; Yin, Y.; Xu, S.J.; Chen, W.S. 5-Fluorouracil: Mechanisms of resistance and reversal strategies. Molecules 2008, 13, 1551-1569. [CrossRef] [PubMed]

100. Yang, Y.; Zhou, Z.; He, S.; Fan, T.; Jin, Y.; Zhu, X.; Chen, C.; Zhang, Z.R.; Huang, Y. Treatment of prostate carcinoma with (galectin-3)-targeted HPMA copolymer-(G3-C12)-5-Fluorouracil conjugates. Biomaterials 2012, 33, 2260-2271. [CrossRef]

101. Evans, A.J. Treatment effects in prostate cancer. Mod. Pathol. Off. J. United States Can. Acad. Pathol. Inc. 2018, 31, 110-121. [CrossRef] [PubMed]

102. Hurwitz, M. Chemotherapy in Prostate Cancer. Curr. Oncol. Rep. 2015, 17, 44. [CrossRef] [PubMed]

103. Andriguetti, N.B.; Raymundo, S.; Antunes, M.V.; Perassolo, M.S.; Verza, S.G.; Suyenaga, E.S.; Linden, R. Pharmacogenetic and Pharmacokinetic Dose Individualization of the Taxane Chemotherapeutic Drugs Paclitaxel and Docetaxel. Curr. Med. Chem. 2017, 24, 3559-3582. [CrossRef]

104. Singh, N.; Sallem, F.; Mirjolet, C.; Nury, T.; Sahoo, S.K.; Millot, N.; Kumar, R. Polydopamine Modified Superparamagnetic Iron Oxide Nanoparticles as Multifunctional Nanocarrier for Targeted Prostate Cancer Treatment. Nanomaterials 2019, 9, 138. [CrossRef]

105. Dasari, S.; Tchounwou, P.B. Cisplatin in cancer therapy: Molecular mechanisms of action. Eur. J. Pharmacol. 2014, 740, 364-378. [CrossRef]

106. Pérez-Herrero, E.; Fernández-Medarde, A. Advanced targeted therapies in cancer: Drug nanocarriers, the future of chemotherapy. Eur. J. Pharm. Biopharm. Off. J. Arb. Fur Pharm. Verfahr. E.V 2015, 93, 52-79. [CrossRef] [PubMed]

107. Nagesh, P.K.B.; Chowdhury, P.; Hatami, E.; Boya, V.K.N.; Kashyap, V.K.; Khan, S.; Hafeez, B.B.; Chauhan, S.C.; Jaggi, M.; Yallapu, M.M. miRNA-205 Nanoformulation Sensitizes Prostate Cancer Cells to Chemotherapy. Cancers 2018, 10, 289. [CrossRef] [PubMed] 
108. Figg, W.D.; Woo, S.; Zhu, W.; Chen, X.; Ajiboye, A.S.; Steinberg, S.M.; Price, D.K.; Wright, J.J.; Parnes, H.L.; Arlen, P.M.; et al. A phase I clinical study of high dose ketoconazole plus weekly docetaxel for metastatic castration resistant prostate cancer. J. Urol. 2010, 183, 2219-2226. [CrossRef] [PubMed]

109. Nagesh, P.K.B.; Johnson, N.R.; Boya, V.K.N.; Chowdhury, P.; Othman, S.F.; Khalilzad-Sharghi, V.; Hafeez, B.B.; Ganju, A.; Khan, S.; Behrman, S.W.; et al. PSMA targeted docetaxel-loaded superparamagnetic iron oxide nanoparticles for prostate cancer. Colloids Surf. B Biointerfaces 2016, 144, 8-20. [CrossRef]

110. Matin, F.; Jeet, V.; Clements, J.A.; Yousef, G.M.; Batra, J. MicroRNA Theranostics in Prostate Cancer Precision Medicine. Clin. Chem. 2016, 62, 1318-1333. [CrossRef] [PubMed]

111. Bhatnagar, N.; Li, X.; Padi, S.K.; Zhang, Q.; Tang, M.S.; Guo, B. Downregulation of miR-205 and miR-31 confers resistance to chemotherapy-induced apoptosis in prostate cancer cells. Cell Death Dis. 2010, 1, e105. [CrossRef]

112. Bettaieb, A.; Wrzal, P.K.; Averill-Bates, D.A. Hyperthermia: Cancer treatment and beyond. In Cancer Treatment-Conventional and Innovative Approaches; Rangel, L., Ed.; InTech Open: London, UK, 2013; pp. 257-283.

113. Nagaraju, G.P.; Srivani, G.; Dariya, B.; Chalikonda, G.; Farran, B.; Behera, S.K.; Alam, A.; Kamal, M.A. Nanoparticles guided drug delivery and imaging in gastric cancer. Semin. Cancer Biol. 2021, 69, 69-76. [CrossRef]

114. Albarqi, H.A.; Demessie, A.A.; Sabei, F.Y.; Moses, A.S.; Hansen, M.N.; Dhagat, P.; Taratula, O.R.; Taratula, O. Systemically Delivered Magnetic Hyperthermia for Prostate Cancer Treatment. Pharmaceutics 2020, 12, 1020. [CrossRef] [PubMed]

115. Li, K.; Nejadnik, H.; Daldrup-Link, H.E. Next-generation superparamagnetic iron oxide nanoparticles for cancer theranostics. Drug Discov. Today 2017, 22, 1421-1429. [CrossRef] [PubMed]

116. Hurley, K.R.; Ring, H.L.; Etheridge, M.; Zhang, J.; Gao, Z.; Shao, Q.; Klein, N.D.; Szlag, V.M.; Chung, C.; Reineke, T.M.; et al. Predictable Heating and Positive MRI Contrast from a Mesoporous Silica-Coated Iron Oxide Nanoparticle. Mol. Pharm. 2016, 13, 2172-2183. [CrossRef] [PubMed]

117. Chikara, S.; Nagaprashantha, L.D.; Singhal, J.; Horne, D.; Awasthi, S.; Singhal, S.S. Oxidative stress and dietary phytochemicals: Role in cancer chemoprevention and treatment. Cancer Lett. 2018, 413, 122-134. [CrossRef]

118. Xie, J.; Yang, Z.; Zhou, C.; Zhu, J.; Lee, R.J.; Teng, L. Nanotechnology for the delivery of phytochemicals in cancer therapy. Biotechnol. Adv. 2016, 34, 343-353. [CrossRef]

119. Saad, F.; Hotte, S.J. Guidelines for the management of castrate-resistant prostate cancer. J. De L'association Des Urol. Du Can. 2010, 4, 380-384. [CrossRef]

120. Fang, Y.; Lin, S.; Yang, F.; Situ, J.; Lin, S.; Luo, Y. Aptamer-Conjugated Multifunctional Polymeric Nanoparticles as CancerTargeted, MRI-Ultrasensitive Drug Delivery Systems for Treatment of Castration-Resistant Prostate Cancer. Biomed Res. Int. 2020, 2020, 9186583. [CrossRef]

121. Ling, Y.; Wei, K.; Luo, Y.; Gao, X.; Zhong, S. Dual docetaxel/superparamagnetic iron oxide loaded nanoparticles for both targeting magnetic resonance imaging and cancer therapy. Biomaterials 2011, 32, 7139-7150. [CrossRef]

122. Montecinos, V.P.; Morales, C.H.; Fischer, T.H.; Burns, S.; San Francisco, I.F.; Godoy, A.S.; Smith, G.J. Selective targeting of bioengineered platelets to prostate cancer vasculature: New paradigm for therapeutic modalities. J. Cell. Mol. Med. 2015, 19, 1530-1537. [CrossRef]

123. Yu, M.K.; Kim, D.; Lee, I.H.; So, J.S.; Jeong, Y.Y.; Jon, S. Image-guided prostate cancer therapy using aptamer-functionalized thermally cross-linked superparamagnetic iron oxide nanoparticles. Small Weinh. Der Bergstr. Ger. 2011, 7, 2241-2249. [CrossRef]

124. Feng, Q.; Liu, Y.; Huang, J.; Chen, K.; Huang, J.; Xiao, K. Uptake, distribution, clearance, and toxicity of iron oxide nanoparticles with different sizes and coatings. Sci. Rep. 2018, 8, 2082. [CrossRef] [PubMed]

125. Liu, G.; Gao, J.; Ai, H.; Chen, X. Applications and potential toxicity of magnetic iron oxide nanoparticles. Small Weinh. Der Bergstr. Ger. 2013, 9, 1533-1545. [CrossRef] [PubMed]

126. Teh, J.; Tripathi, M.; Reichel, D.; Sagong, B.; Montoya, R.; Zhang, Y.; Wagner, S.; Saouaf, R.; Chung, L.W.K.; Perez, J.M. Intraoperative assessment and postsurgical treatment of prostate cancer tumors using tumor-targeted nanoprobes. Nanotheranostics 2021, 5 , 57-72. [CrossRef] [PubMed]

127. Malhotra, N.; Lee, J.S.; Liman, R.A.D.; Ruallo, J.M.S.; Villaflores, O.B.; Ger, T.R.; Hsiao, C.D. Potential Toxicity of Iron Oxide Magnetic Nanoparticles: A Review. Molecules 2020, 25, 3159. [CrossRef] [PubMed] 